\begin{abstract}
UNIVERSIDADE DE SÃO PAULO
FACULDADE DE FILOSOFIA, LETRAS E CIÊNCIAS HUMANAS

DEPARTAMENTO DE LETRAS MODERNAS

PROGRAMA DE PÓS-GRADUAÇÃO EM LÍNGUA ESPANHOLA E LITERATURAS

ESPANHOLA E HISPANO-AMERICANA
\end{abstract}

KATIA APARECIDA DA SILVA OLIVEIRA

A VOZ DO AUTOR NO LAZARILLO DE TORMES

São Paulo

2008 


\author{
UNIVERSIDADE DE SÃO PAULO \\ FACULDADE DE FILOSOFIA, LETRAS E CIÊNCIAS HUMANAS \\ DEPARTAMENTO DE LETRAS MODERNAS \\ PROGRAMA DE PÓS-GRADUAÇÃO EM LÍNGUA ESPANHOLA E LITERATURAS \\ ESPANHOLA E HISPANO-AMERICANA
}

\title{
A VOZ DO AUTOR NO LAZARILLO DE TORMES
}

Katia Aparecida da Silva Oliveira

Dissertação de mestrado apresentada ao Programa de Pós-Graduação em Língua Espanhola e Literatura Espanhola e HispanoAmericana, do Departamento de Letras Modernas da Faculdade de Filosofia, Letras e Ciências Humanas da Universidade de São Paulo.

Orientador: Professor Dr. Mario Miguel González

São Paulo 
Àqueles que amo e que fazem de mim uma pessoa melhor a cada dia. 


\section{AGRADECIMENTOS}

Ao professor Mario M. González pela atenciosa orientação, pelo carinho e paciência com que me recebeu tantas vezes durante os últimos anos e pela amizade que fomos construindo.

À professora Valéria de Marco e ao professor Ivan Rodrigues Martin pela forma como me acolheram no exame de qualificação e pelas sugestões e críticas que fizeram ao meu trabalho naquele momento.

Ao Alan, meu companheiro nessa jornada que é a vida, por saber respeitar os meus silêncios e por me ouvir sem que eu precise pronunciar nenhuma palavra.

À minha família e amigos que sempre estiveram ao meu lado, apoiandome quando necessário e comemorando as conquistas que tivemos.

À Dulce, pela revisão desse trabalho e pela amizade que construímos. 


\section{RESUMO}

Neste trabalho pretendemos realizar uma leitura do Lazarillo de Tormes que além de considerar o discurso do narrador, Lázaro de Tormes, considere também a voz do autor implícito dentro da obra e a forma como essa voz influencia a construção do sentido dela.

Reconhecendo a voz desse autor implícito no prólogo da obra e em meio ao discurso do narrador, é possível identificar a sua perspectiva, que nem sempre coincide com a do narrador. $O$ encontro dessas diferentes perspectivas forma contradições no discurso de Lázaro como narrador, e é na conjunção dessas perspectivas que consideramos formar-se o sentido da obra.

Palavras chave: Lazarillo de Tormes, romance picaresco, autor implícito, narrador. 


\section{ABSTRACT}

The aim of this work is to accomplish a reading of Lazarillo de Tormes considering the discourse of the narrator and also the voice of the author within the story and how it influences the construction of its sense.

By recognizing the voice of this implicit author in the prologue of the story among the narrator's discourse it is possible to identify the perspective of the author which is not always the same of the narrator. The encounter of these two perspectives forms some contradictions in Lázaro's discourse as the narrator and it is through this conjunction that we consider to be forming the sense of the novel.

Key words: Lazarillo de Tormes, picaresque novel, implicit author, narrator. 


\section{SUMÁRIO}

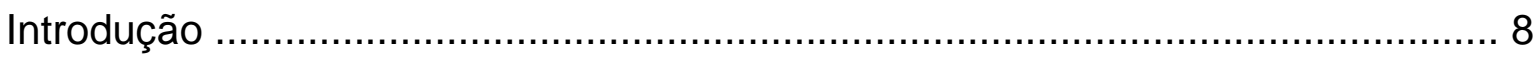

Capítulo 1

A construção literária: autor implícito, narrador e leitor implícito 12

Capítulo 2

Algumas considerações sobre o romance picaresco e o Lazarillo de Tormes 27

Capítulo 3

A voz do prólogo 42

Capítulo 4

A voz de Lázaro 58

1. Uma carta a Vuestra Merced 58

2. Lázaro como narrador e como personagem 62

2.1. Lázaro e seus pensamentos .......................................... 65

2.2. Lázaro como narrador................................................ 75

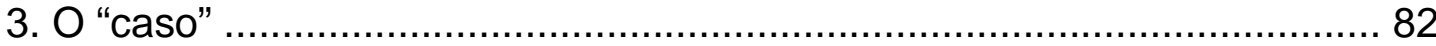

Capítulo 5

A voz do autor implícito na narrativa de Lázaro de Tormes

Capítulo 6

A construção do sentido no Lazarillo de Tormes ................................................. 101

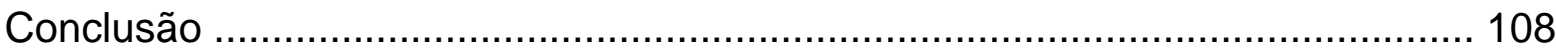

Referências Bibliográficas ...................................................................... 113 


\section{INTRODUÇÃO}

Escrever sobre o Lazarillo de Tormes não é uma novidade. Há muito essa obra é foco de estudos críticos que a analisam a partir de distintos pontos de vista.

Neste trabalho, pretendemos desenvolver uma leitura do Lazarillo que considere, além daquilo que a crítica vem dizendo sobre o romance, a maneira como foi construído e organizado o seu texto e, com isto, como se forma o seu sentido.

Dessa maneira, dividimos esse trabalho em seis capítulos, tentando primeiro apresentar a nossa visão sobre alguns aspectos teóricos que aplicamos nele e, depois apresentando a nossa visão sobre a construção do sentido do Lazarillo de Tormes. Partimos da apresentação da obra e, em seguida, a estudamos desde o prólogo ao discurso de Lázaro, desde a voz do narrador à do autor implícito e na relação estabelecida entre elas.

No primeiro capítulo desse trabalho intitulado "A construção literária: autor implícito, narrador e leitor implícito" tratamos da questão da construção da obra literária considerando além da sua estrutura formal, a construção de seu sentido. Partindo do estudo teórico do autor implícito, baseando-nos, principalmente em Wayne Booth(1980), iniciamos o capítulo que segue com algumas definições do narrador, de sua tipologia e funções literárias.

No primeiro capítulo, pareceu-nos interessante, também, pensar na importância do leitor implícito ou leitor real para a construção de uma obra. Seja no 
processo de escritura ou em sua leitura, esses elementos acabam por influenciar substancialmente o sentido que tem, ou seja, ao escrever, o autor imagina o tipo de leitor que terá acesso à sua criação e a desenvolve a partir da imagem que projetou. Pensando no leitor real, por outro lado, o sentido de uma obra se completa somente a partir da leitura e do sentido que ele imprime nela.

Seguindo com o trabalho, depois de abordar essas questões teóricas, começamos a tratar mais especificamente do Lazarillo de Tormes e do romance picaresco. O segundo capítulo apresenta o romance picaresco e a sua origem. Nele temos uma breve apresentação do Lazarillo, da sua estrutura e de algumas questões importantes para a sua interpretação.

Uma dessas questões diz respeito à divisão do romance em tratados, que consideramos arbitrária, já que, atualmente, parte da crítica, apoiada principalmente em Francisco Rico (1988), acredita que essa divisão não faria parte do manuscrito da obra, sendo de responsabilidade de seu primeiro editor.

Ao considerar arbitrária a divisão da obra, podemos repensar também o seu prólogo, que apresenta claramente uma ruptura discursiva. Segundo Navarro Durán (2003), no prólogo do Lazarillo há dois diferentes discursos: um que seria o real prólogo da obra, e outro que apresentaria o início do discurso do narrador.

Iniciamos o nosso terceiro capítulo com um estudo do prólogo definindo o papel deste tipo de texto em uma obra e interpretando a voz que o apresenta, voz que acreditamos ser do autor implícito.

No prólogo do Lazarillo encontramos um autor implícito que demonstra ter erudição e um olhar crítico aguçado. Seguindo os elementos que compunham os prólogos comuns à época, ele apresenta o romance, esclarece quais são os seus 
objetivos com a obra e a defende. Interpretando, assim, o discurso presente no prólogo, começamos a compreender a perspectiva adotada por esse autor implícito em relação à sua criação.

Mas a voz do autor implícito não aparece somente no prólogo do romance. Ao longo da narrativa de Lázaro, a voz do autor implícito se mostra camuflada no discurso do narrador e para identificá-la, foi necessário um estudo aprofundado desse discurso.

O quarto capítulo de nosso trabalho apresenta esse estudo. Compreendendo que o relato de Lázaro é autobiográfico, observamos que nos encontramos nesse relato com dois Lázaros: um que é o narrador de suas experiências e outro que é personagem das experiências narradas.

Tanto como personagem de suas lembranças ou como narrador, Lázaro emite comentários críticos. Como personagem, esses comentários aparecem na narrativa em forma de pensamentos citados. Como narrador, Lázaro expressa comentários críticos relacionados às situações que vivenciou.

Estudando os comentários críticos de Lázaro como narrador ou como personagem de seu relato, percebemos a formação de contradições. Dizemos que se formam contradições porque os comentários críticos do discurso de Lázaro se opõem à prática e postura assumidas pela personagem no seu presente.

Acreditamos que as contradições do discurso de Lázaro são formadas pela junção de dois diferentes pontos de vista: o do narrador, e o do autor implícito. Reconhecendo que a perspectiva do narrador e a do autor implícito são diferentes, compreendemos que na sua conjunção são construídas contradições. 
Identificando tais contradições podemos reconhecer o ponto de vista do autor implícito e interpretá-lo, relacionando-o a toda a obra. Isso é o que fazemos no quinto capítulo.

Interpretando as contradições estabelecidas entre o ponto de vista do narrador e o do autor implícito, podemos aproximá-los e compreender como se forma o sentido do Lazarillo. Assim, no sexto capítulo, buscamos interpretar o Lazarillo a partir das diferentes perspectivas que apresenta formando as suas contradições.

Buscamos, nesse trabalho, enfim, apresentar uma outra leitura do Lazarillo de Tormes, considerando, além da voz do narrador, a voz do autor implícito da obra, e compreendendo como se forma o sentido desse romance. 


\section{CAPÍTULO 1}

\section{A CONSTRUÇÃO LITERÁRIA: AUTOR IMPLÍCITO,}

\section{NARRADOR E LEITOR IMPLÍCITO}

Em literatura, um questionamento recorrente diz respeito ao papel que ocupa o autor em suas obras. É comum que um ou outro leitor tente traçar relações entre os acontecimentos presentes em uma determinada narrativa e a vida pessoal do escritor.

Nem sempre essas relações se comprovam, mesmo em casos de narrativas autobiográficas. $\mathrm{O}$ autor é um criador, e mesmo uma narrativa que se pretenda "real", como a autobiografia, não deixa de ser uma criação ou, dizendo de outra maneira, uma recriação, uma representação de algo que pode haver acontecido em algum momento.

Não podemos negar também que, ao escrever, o autor se faz presente em sua obra. As suas escolhas, que vão desde o tipo de narrador que escolhe às personagens que cria, desde a definição do tempo à delimitação do espaço em que se desenvolve a narrativa, dentre outros elementos, são a sua marca dentro da obra. Ao escolher um determinado elemento para compor a sua narrativa, o autor mostra-se nela. Como diz Booth (1980:35):

O autor está presente em todos os discursos de qualquer personagem a quem tenha sido conferido o emblema de credibilidade, seja de que modo for. 
As escolhas do autor são um reflexo que tornam inegável a sua presença em cada uma de suas obras, uma vez que como criador, sempre imprimirá nelas algo de seu. A criação de um determinado tipo de narrador ou de uma personagem revela um laço existente entre o criador e a criação literária, demonstra que o autor tem consciência de seu papel criativo e sabe qual tipo de impressão pode chegar a obter com as escolhas que faz ou deixa de fazer para a sua obra. É pensando exatamente na relação do autor com as personagens que cria, que comenta Bakhtin (2003:10-11):

\begin{abstract}
Autor: é o agente da unidade tensamente ativa do todo acabado, do todo da personagem e do todo da obra, e este é transgrediente a cada elemento particular desta. Na medida em que nos compenetramos da personagem, esse todo que a conclui não pode ser dado de dentro dela em termos de principio e ela não pode viver dele nem por ele guiar-se em seus vivenciamentos e ações, esse todo the chega de cima para baixo como um dom - de outra consciência criadora do autor. A consciência do autor é a consciência da consciência, isto é, a consciência que abrange a consciência e o mundo da personagem, que abrange e conclui essa consciência da personagem com elementos por princípio transgredientes a ela mesma e que, sendo imanentes, a tornariam falsa. $O$ autor não só enxerga e conhece tudo o que cada personagem em particular e todas as personagens juntas enxergam e conhecem, como enxerga e conhece algo que por princípio é inacessível a elas, e nesse excedente de visão e conhecimento do autor, sempre determinado e estável em relação a cada personagem, é que se encontram todos os elementos do acabamento do todo, quer das personagens, quer do acontecimento conjunto de suas vidas, isto é, do todo da obra.
\end{abstract}

Para Bakhtin, o autor detém todo o conhecimento da obra que cria, é, como ele mesmo diz, a "consciência da consciência" da obra e, como possui a consciência do todo da obra que constrói, é dele a consciência da criação e dentro dela, da ação que a estrutura. Um exemplo dessa consciência criativa são as personagens de suas obras. Essas personagens não têm e nunca terão a consciência do todo da obra, só lhes é dado saber o que é necessário e o que lhes 
cabe sendo parte dela. As personagens não se criam por si só, ao contrário, são o fruto de um ato de criação consciente de seu autor.

Partindo do comentário de Bakhtin, temos a impressão de que essa consciência que é o autor, parece "pairar" sobre a obra como um ser criador, como um elemento que ao mesmo tempo está dentro e fora dela.

Mas esse criador, mesmo que inegavelmente esteja presente em sua obra, mostra-se, ou melhor, deixa-se perceber nela de uma forma sutil. Sua ação criadora está oculta e metamorfoseada nos elementos narrativos que seleciona e aplica em sua criação. Como diz Maria Lucia Dal Farra (1978:19) comentando a obra de Wolfgang Kayser ${ }^{1}$ :

O homem responsável pelo romance, cujo nome aparece na capa, traz a sua face apagada dentro da ficção. Seu rosto está encoberto pelos véus da mistificação romanesca e seu olhar velado pela perspectiva do narrador que criou. Ele tece os fios, distende-os e reajusta-os conforme as necessidades teleológicas da obra que está gerando, mas as suas mãos artificiosas - lugar de origem da criação - não fazem parte da cena. Seu lugar é o dos bastidores e o seu espaço é o do romance, aquele onde, pouco a pouco, as diferentes fisionomias da sua invenção - a enorme família das suas metamorfoses - vão brotando e exalando vida.

O autor de uma obra, sendo o criador dela, não pode chegar a ser ou mesmo transformar-se em sua criação. Ele se faz presente na obra a partir de suas escolhas, cria um universo narrativo, a ponto de que possamos percebê-lo em sua criação, mas ele nunca será a sua obra.

Embora um autor possa ser percebido dentro de suas obras, ele nem sempre é o mesmo. O homem que é o autor de uma determinada obra na vida real,

\footnotetext{
${ }^{1}$ KAYSER, Wolfgang. "Qui raconte le roman?" Poétique 4. Paris, Seuil, 1970. p. 498-510. Apud DAL FARRA, 1978:19.
} 
o homem físico, está em constante mudança. Ele não é o mesmo homem a cada obra que escreve, e ao escrever, não é o autor "real" que se projeta em sua obra, não é o homem existente no mundo aquele que percebemos, mesmo porque esse homem real pode transformar-se durante o seu processo de criação, pode não ser o mesmo homem o que deu início à obra e aquele que a finalizou.

O que encontramos dentro de cada obra não é a presença do autor "real" dela, e sim uma "versão" que o autor cria de si mesmo ao escrever. Explicando melhor, a forma como o autor se faz presente na obra não é necessariamente a mesma como se apresenta no mundo real. Ao escrever, o autor cria uma versão de si mesmo, uma criação artística na qual estão implicados os seus objetivos para aquela obra.

Booth (1980: 88,92) apresenta a diferença existente entre o que chamou de autor real e autor implícito de uma obra. O autor real é para ele o indivíduo, a pessoa responsável pela criação de uma obra, e que, resumindo, existe no mundo "real"; o autor implícito, por outro lado, é uma criação do autor real que só existe em sua obra. Nas palavras do autor:

Enquanto escreve, o autor não cria, simplesmente, um "homem em geral", impessoal, ideal, mas sim uma versão implícita de "si próprio", que é diferente dos autores implícitos que encontramos nas obras de outros homens. Na verdade, pareceu a alguns romancistas que se estavam a descobrir ou a criar à medida que escreviam. Como diz Jessamyn West, por vezes é como se "só escrevendo a história o romancista pudesse descobrir não a sua história, mas o escritor, o escriba oficial, por assim dizer, para essa narrativa". Quer adoptemos para este autor implícito a referência "escriba oficial", ou o termo recentemente redescoberto por Kathleen Tillotson - o "alter ego" do autor - é claro que aquilo de que o leitor se apercebe nesta presença são os efeitos mais importantes do autor. Por impessoal que ele tente ser, o leitor construirá, inevitavelmente, uma imagem do escriba oficial que escreve desta maneira - e, claro, esse escriba oficial nunca será neutral em relação a todos os valores. A nossa reacção aos seus vários compromissos, secretos ou a descoberto, ajudará a determinar a nossa resposta à obra. 
O "autor implícito" escolhe, consciente ou inconscientemente, aquilo que lemos; inferimo-lo como versão criada, literária, ideal dum homem real ele é a soma das opções deste homem.

O autor implícito é, enfim, uma criação literária, uma espécie de alter ego do autor real dentro da obra. Formam-se assim, diante de nós, duas perspectivas diferentes de autoria. Temos, segundo a definição de Booth, a possibilidade de considerar que uma obra literária conte com um autor real e com o autor implícito que se mostra como uma projeção desse autor real dentro da obra, como seu porta-voz criado para refletir dentro da obra o que lhe interessa.

A cada obra que escreve, o autor real cria um autor implícito diferente para si mesmo, uma outra versão de si, como uma espécie de reflexo do que pensava e acreditava no momento em que escrevia. O autor implícito de uma obra estará sempre presente nela, imutável como os outros elementos da narrativa, bastante diferente do autor real que se mantém em permanente mutação.

O autor implícito de uma obra, além de ser o responsável pela sua organização e pela escolha dos elementos que a compõem, sendo ele uma espécie de representação do autor dentro da obra, um reflexo de seus desejos para a sua criação, não deixa de ser também o seu porta voz.

Sendo parte da obra, o autor implícito se faz presente nela, mas não explicitamente, sua presença é sutil, porém pode ser percebida. Esse autor implícito imprime na obra um ponto de vista que pode ou não ser o mesmo do narrador ou das personagens que a compõem, o ponto de vista de quem está fora da narrativa, daquele que tem uma visão do todo da obra e dos possíveis sentidos presentes nela. 
A voz do autor implícito é quase imperceptível; estando integrada ao discurso do narrador ou de uma personagem, por meio de uma intrusão ou mesmo de um comentário, adere aos discursos que formam a narrativa e faz-se ouvir.

Estando tão camufladas nos discursos presentes na obra, muitas vezes a presença e a voz do autor implícito não são percebidas facilmente, em geral, essa voz que se impõe ao longo de uma narrativa é interpretada como a voz do narrador ou das personagens dela.

Sendo o narrador o componente da narrativa que abertamente é o responsável pela sua apresentação, é comum que se confundam para o leitor a sua voz e a do autor implícito. Muitas vezes, também, principalmente no caso de narrativas em primeira pessoa, percebemos uma tendência a que os leitores confundam a voz do narrador com a voz do autor, mas não a do autor implícito, que se mostra sutilmente ao longo da narrativa, a do autor real que tem seu nome vinculado explicitamente à obra.

É comum que leitores confundam o autor e o narrador de uma obra, principalmente quando elas apresentam narradores em primeira pessoa. Talvez tal confusão possa ser explicada se pensarmos, acompanhando o raciocínio de Walter Benjamin (1994:198), nas origens do narrador:

A experiência que passa de pessoa a pessoa é a fonte a que recorreram todos os narradores. E, entre as narrativas escritas, as melhores são as que menos se distinguem das histórias orais contadas pelos inúmeros narradores anônimos. Entre estes, existem dois grupos, que se interpenetram de múltiplas maneiras. A figura do narrador só se torna plenamente tangível se temos presentes esses dois grupos. 'Quem viaja tem muito que contar', diz o povo, e com isso imagina o narrador como alguém que vem de longe. Mas também escutamos com prazer o homem que ganhou honestamente sua vida sem sair do seu país e que conhece suas histórias e tradições. Se quisermos concretizar esses dois grupos através dos seus representantes arcaicos, podemos dizer que um é 
exemplificado pelo camponês sedentário, e outro pelo marinheiro comerciante.

As origens do narrador, conforme diz Benjamin, estariam relacionadas aos antigos contadores de histórias, àqueles que tinham não só o poder de narrar mas também o que narrar. A associação que Benjamin faz dos primeiros narradores com os marinheiros ou com os camponeses deixa clara a idéia do narrador ser, antes de qualquer coisa, aquele que realmente havia vivido, conhecido ou visto algo que poderia ser o motivo e a matéria de uma narração.

Benjamim estava pensando nas origens do narrador, e desde as suas origens, os narradores foram se transformando e hoje, embora ainda tenhamos a sensação dos narradores serem verdadeiras testemunhas do que narram, sabemos que já não estamos lidando com um homem que narra o que vivenciou, mas com um elemento que é fruto de uma construção intelectual, lidamos com um elemento criado literariamente.

O narrador que temos hoje pode apresentar-se de diferentes maneiras, estando mais ou menos envolvido com o que narra. Esse componente da narrativa é mais um artifício criado por um autor literário para dar à sua obra o sentido, ou sentidos que planeja.

Não temos mais no narrador um ser real, mas um ser criado, o que por vezes pode causar no leitor um certo embaraço, alguma confusão, já que quando se encontra em frente ao texto, o leitor entra em contato direto com este elemento que conta a história. O narrador, dessa forma, toma vida e apresenta ao leitor o que é, no fim das contas, a sua responsabilidade dentro da obra literária, ele conta uma história. 
Atualmente temos basicamente dois tipos de narradores, um desses tipos é formado por aqueles que participam da narrativa, os narradores em primeira pessoa, que são personagens da narrativa e podem ser os seus protagonistas ou espectadores. Esses narradores em geral estão bastante comprometidos com o que narram, já que a narrativa é composta de suas próprias experiências, é a opinião que têm sobre um acontecimento a apresentada por eles.

O outro tipo de narradores que temos são aqueles que mantêm um distanciamento da narrativa, os narradores em terceira pessoa. Em geral temos com esses narradores uma narrativa um pouco mais objetiva do que teríamos com os narradores em primeira pessoa. Esses narradores podem, além de narrar os fatos que compõem uma história, chegar a conhecer os pensamentos das personagens, suas impressões e sensações.

Sobre estes dois tipos de narrador, diz Kayser:

En las narraciones presentadas por un narrador ficticio es frecuente que el narrador cuente los hechos como si los hubiera vivido. A este modo de narrar se le da el nombre de narración en primera persona (narración subjetiva: Ich Erzählung). Lo opuesto es la narración en tercera persona (narración objetiva: Er Erzählung), en la cual el autor o el supuesto narrador queda fuera del plano de los acontecimientos.

O fato de narrar a partir de uma posição mais distanciada, não faz do narrador em terceira pessoa um narrador descompromissado com o seu ponto de vista. Esse ponto de vista pode ser mais ou menos velado, mas não podemos dizer que exista uma narração totalmente neutra.

O ponto de vista do narrador está intimamente relacionado à posição de onde narra. Um narrador em primeira pessoa está limitado às suas experiências, 
àquilo que como personagem viu ou ouviu. Esse narrador não tem acesso, por exemplo, ao que se passa na mente de outras personagens, tudo o que conta está relacionado a si mesmo, aos seus interesses. $\mathrm{O}$ narrador em primeira pessoa tem um compromisso consigo. Ele seleciona e narra o que the é interessante, enfim, o seu ponto de vista é pessoal.

Temos algo diferente com o narrador em terceira pessoa, já que este narrador mantém alguma distância do narrado por não ser personagem do que narra. O narrador em terceira pessoa mostra-se como um observador do que narra e não está limitado às suas experiências como acontece com o narrador em primeira pessoa, o que não quer dizer que o seu ponto de vista não seja comprometido com algo.

O ponto de vista do narrador é aquele a que estão sujeitos os leitores. A perspectiva de onde narra, os comentários que emite ou omite, a forma como apresenta as personagens, etc, acabam sendo fundamentais para a construção do sentido de uma obra. Sobre o ponto de vista diz Kayser (1961:274):

\begin{abstract}
La narración en prosa - contrariamente a lo que ocurre en la epopeya, en el poema y aun en la novela corta - concede al autor libertad absoluta para la elección del punto de vista del "narrador" respectivo. Sería un crimen contra el espíritu de la narración exigir una actitud narrativa estrictamente "objetiva", eliminando en lo posible el elemento subjetivo del narrador. El arte narrativo quedaría de este modo privado de buena parte de sus ricas posibilidades, y sería fácil demostrar que el valor artístico y la fuerza vital de las grandes novelas inglesas del siglo XVIII - de un Fielding, Goldsmith, Sterne, etc - reside en gran parte en la acertada elección y en el firme mantenimiento del punto de vista narrativo.
\end{abstract}

O ponto de vista de um narrador, é mais uma escolha do autor implícito de uma obra. Esse ponto de vista pode contribuir para a construção do sentido da obra, o que faz dele um dos principais componentes de uma narrativa. 
Dentro de uma obra literária, o narrador mostra-se com um elemento importante para a sua estruturação. É ele o responsável pela apresentação da narrativa, é ao seu ponto de vista que estão sujeitos os leitores, e é a esse elemento literário que responsabilizamos pela organização explícita da narrativa.

Dizemos que o narrador é o responsável pela organização explícita da narrativa porque é com ele que, como leitores, temos um contato direto, porém, não podemos nos esquecer de que ele não deixa de ser um elemento narrativo criado por um autor implícito, a quem realmente devemos responsabilizar pela criação e organização da obra literária. É como diz Wolfgang Kayser (1961:261):

\footnotetext{
Por medio de un artificio técnico puede concretarse e intensificarse esta situación: el autor se oculta detrás de otro narrador, en boca del cual pone la narración. Precisamente la narración, cuyo nombre indica ya que en ella se manifiesta del modo más patente la situación primitiva del narrar, ha gustado siempre de este recurso.
}

O autor de que trata Kayser, pode ser associado àquilo que consideramos ser o autor implícito. Kayser afirma que esse "autor" ocultando-se atrás da figura do narrador, apresenta a partir desta máscara aquilo que tem a dizer.

O narrador acaba mostrando-se como um elemento manipulável já que o tipo de narrador apresentado em uma obra, seja ele um narrador personagem ou um narrador em terceira pessoa, é uma escolha consciente do autor implícito.

As escolhas do autor implícito podem criar narradores dos mais diversos, com diferentes tipos de manifestações, de formas de narrar. Pensando nas possíveis manifestações de um narrador, diz Bobes Naves (1993:30): 
La función del narrador no se limita a narrar, puede ampliarse a la propia de un técnico de montaje de episodios; el narrador puede ser también comentarista, interior o voz in off, que aclara relaciones o términos del discurso o de la historia; el narrador puede presentarse como un censor, un moralista, establecer el canon de cualquier tipo, con una función valorativa.

Sendo o narrador quem apresenta e organiza explicitamente a narrativa, não é de surpreender que possa apresentá-la de diferentes maneiras, como, por exemplo, as citadas por Bobes Naves. Mesmo o seu ponto de vista mostra-se claro, seja em comentários, em descrições e até em silêncios.

É quando reconhecemos o ponto de vista do narrador que nos encontramos com a dificuldade de diferenciar o discurso do narrador do discurso do autor implícito.

As relações entre narrador e autor implícito são estreitas, uma vez que o autor implícito, na maior parte das vezes, está diluído em meio à estrutura da obra. Porém, ainda que esteja diluído em meio à narrativa, não se pode afirmar que a sua voz esteja abafada nela.

Já vimos, que o autor implícito pode deixar que sua voz seja percebida na narrativa. Muitas vezes, ele se faz ouvir através de intromissões, seja nos discursos das personagens ou mesmo no discurso do narrador, uma vez que é ele o responsável pela organização da obra.

Vez ou outra, podemos perceber em uma narrativa um comentário em meio ao discurso do narrador não condizente com o discurso que vem sendo desenvolvido por ele. Em outros momentos percebemos em meio às falas de algumas personagens algo nem sempre conveniente para a sua construção, algo que poderia ou não fazer parte de seu ponto de vista, mas que está mais relacionado ao ponto de vista do autor implícito que delas. 
Identificar a presença do autor implícito em suas obras pode não ser tão fácil como parece. É preciso reconhecer o seu ponto de vista nas entrelinhas, em comentários, em intromissões. Muitas vezes, para reconhecê-lo, precisamos analisar a obra em seus detalhes, e principalmente fixar-nos na figura do narrador.

Dissemos que temos de fixar-nos na figura do narrador, porque como esse é o elemento que organiza a obra explicitamente, já que é ele quem narra, quem apresenta abertamente o seu ponto de vista, é nele que muitas vezes percebemos os reflexos ou mesmo a perspectiva do autor implícito.

Reconhecer a voz do autor implícito ou mesmo perceber a sua mão na organização de uma obra possibilita que desenvolvamos diferentes leituras dela, possibilita entender a forma como o sentido da obra é construído, desde a seleção dos elementos que compõem a sua narrativa, até a forma como essa narrativa é desenvolvida pelo narrador e pelo autor implícito.

Por outro lado, o sentido que recebe uma obra nem sempre depende exclusivamente de sua construção, mas também de quem a lê. O leitor é no final das contas o responsável pela organização dos sentidos de uma obra, a partir de sua leitura completa-se a construção do sentido dela.

Ao escrever, o autor real imagina quem será o leitor ou leitores de sua obra e, de certa maneira, essa idéia também se projeta nela, afinal, quem escreve, escreve para alguém.

Acontece que, como vimos, o autor real da obra cria um alter ego para si mesmo que é seu reflexo em sua criação. Este ser real cria um elemento que o representa, e é este alter ego, o autor implícito, o responsável pela organização da obra e pelo seu direcionamento para o leitor que provavelmente terá acesso a ela. 
Não é possível que se saiba exatamente quem terá acesso à obra literária, mas pode-se projetar uma imagem desse leitor, um leitor implícito. Vejamos abaixo o que diz Booth (1980: 153) a respeito desta questão:

[...] Em resumo, o autor cria uma imagem de si próprio e uma imagem do leitor; faz o seu leitor, tal como faz o seu alter ego; e a leitura mais bem sucedida é aquela em que os eus criados - autor e leitor - entram em acordo perfeito.

É claro que nem sempre o leitor real entra em acordo com o autor implícito. Estão em jogo em sua leitura não só os valores, crenças e ideais presentes no texto, mas também aqueles que fazem parte do leitor mesmo.

O papel do leitor torna-se então mais complexo. Há no texto uma projeção do que seria um leitor ideal, um leitor que decodificaria e contribuiria para a construção do sentido da obra conforme foi planejada, inclusive preenchendo os vazios que pudessem compô-la. Diz Luiz Costa Lima (2002:50):

\begin{abstract}
Passemos à relação texto-leitor. Embora nesta haja a diferença acentuada de o leitor não conhecer a relação do "parceiro", há, no entanto, um dado comum: também os textos - e não só os ficcionais - tampouco são figuras plenas, mas, ao contrário, enunciados com vazios, que exigem do leitor o seu preenchimento. Este se realiza perante a projeção do leitor. A comunicação entre o texto e o leitor fracassará quando tais projeções se impuserem independentes do texto, fomentadas que serão pela própria fantasia ou pelas expectativas estereotipadas do leitor. Ao invés, a comunicação de êxito dependerá de o texto forçar o leitor à mudança de suas "representações projetivas" habituais.
\end{abstract}

Ainda que uma obra conte com a projeção de um leitor implícito, esse nem sempre coincide com o leitor real, nem sempre a idéia implícita de leitor presente no texto é correspondente ao real leitor que tem acesso a ela. Isso implica 
em uma leitura aquém da imaginada pelo autor da obra, uma leitura que pode entrar em conflito com os sentidos apresentados para a obra por seu autor implícito.

Para Booth (1980:153) o leitor é dividido em duas partes: aquele que é o leitor em si, e o homem que vive no mundo. Como leitor, esse homem em certa medida integra-se ao texto e, adotando a visão apresentada pelo autor implícito, contribui para o sentido da obra. Mas esse homem não consegue desvencilhar-se de sua outra parte, daquela em que estão instalados os seus valores e crenças, assim algumas vezes o leitor implícito projetado pelo autor, não entra em acordo com o autor implícito da obra. Comenta ainda Booth (1980: 153):

\begin{abstract}
Podemos exortar-nos a ler com tolerância, podemos citar Coleridge, sobre a suspensão voluntária da descrença até que nos achemos totalmente suspensos num universo relativista e, mesmo assim, continuamos a encontrar muitos livros que postulam leitores que nos recusamos a ser, livros que dependem de "crenças" ou "atitudes" - não importa aqui o termo - que não podemos adoptar como nossas, nem hipoteticamente.
\end{abstract}

O leitor real pode não corresponder às expectativas e à imagem de leitor implícito presentes em uma obra, como leitores podemos, como diz Booth, nos recusar a ser esses leitores idealizados por alguém.

Havendo ou não esse conflito na relação entre o leitor implícito e o leitor real de uma obra, é certo que o leitor implícito, sendo uma projeção do autor, pode influenciar a leitura que poderá ser feita dela.

No caso do Lazarillo de Tormes, obra que analisamos neste trabalho, considerando as suas diferentes possibilidades de interpretação, acreditamos ser de vital importância o reconhecimento e análise da participação do autor implícito e 
do narrador ao longo da narrativa para que entendamos a construção de alguns dos sentidos do romance.

Porém, se temos como foco tratar exatamente da construção de alguns dos sentidos desse romance, não poderemos deixar de considerar também nesta análise, o papel do leitor implícito da obra, uma vez que, como vimos, esse é também um elemento que contribui para o desenvolvimento das diferentes possibilidades de interpretação de uma obra.

Sabendo que tanto o autor implícito como o leitor implícito são projeções do autor na obra, e que ambos contribuem para a construção dos sentidos que possa ter, ignorar um ou outro desses elementos neste trabalho, não seria possível, já que limitaria a interpretação que pretendemos desenvolver do romance picaresco Lazarillo de Tormes. 


\section{CAPÍTULO 2}

\section{ALGUMAS CONSIDERAÇÕES SOBRE O}

\section{ROMANCE PICARESCO E O LAZARILLO DE TORMES}

O romance picaresco compõe uma modalidade literária das mais discutidas: são motivos de discussão tanto a sua origem como as suas características, as obras que fazem parte dele e até mesmo a possibilidade de ser visto muito mais como um contragênero do que como um gênero, uma vez que quando surgiu, no século XVI, seguia a contracorrente dos gêneros literários existentes naquele momento.

Consideramos que o romance picaresco se estabeleceu como modalidade literária a partir da publicação, em 1599, da obra de Mateo Alemán "Guzmán de Alfarache", que seguia o modelo de narrativa existente em uma obra publicada em meados do século XVI (provavelmente entre 1552 e 1553, uma vez que não temos a primeira edição dessa obra), e de autoria desconhecida: "La vida de Lazarillo de Tormes y de sus fortunas y adversidades".

Não podemos negar a existência de algumas características recorrentes nos romances que consideramos ser picarescos, e são exatamente estes elementos que são levados em conta para a definição dessa modalidade literária. Em uma tentativa de definição do romance picaresco, levantando o que para ele são as suas características essenciais, temos os comentários de Mario González (2005:201): 
tentar definir o que é um romance picaresco não é tarefa fácil. (...) No entanto, procurando um enunciado mais sintético, propomos entender o romance picaresco como a pseudo-autobiografia de um anti-herói - o pícaro - , definido como um marginal à sociedade, cujas aventuras, por sua vez, são a síntese crítica de um processo de tentativa de ascensão social pela trapaça e representam uma sátira da sociedade de sua época.

A existência de um pícaro que apresenta a sua autobiografia é um elemento essencial do romance picaresco. A vida do pícaro, personagem central desse tipo de romance, é o seu fio condutor, o que faz com que esta narrativa se transforme em uma espécie de retrato de um tipo social e do meio a que se encontra vinculado.

O pícaro não deixa de ser uma personagem interessante: é um anti-herói que protagoniza um romance, uma vez que este romance contém a sua autobiografia. Com essa autobiografia, o pícaro, que é um marginal, ocupa no romance picaresco uma posição privilegiada, já que a voz que o conduz é dele, é seu o discurso que compõe a narrativa, ele é o narrador que a apresenta e que constrói a sua autobiografia.

A aparição de uma personagem marginal como personagem principal de um gênero literário, pode ser vista como uma ruptura com o tipo de literatura que então se produzia no século XVI. Os pícaros são o oposto dos cavaleiros que protagonizavam as novelas de cavalaria, gênero dos mais populares na época. Vejamos o que diz Américo Castro (1957:85):

[...]el pícaro es el antihéroe, y la novela picaresca nace sencillamente como una reacción antiheroica, en relación con el derrumbamiento de la caballería y de los mitos épicos, y con la peculiar situación de vida que se crearon los españoles desde fines del siglo XV. 
É justamente a partir da relação de oposição criada entre o romance picaresco e as outras formas literárias da época, como as novelas de cavalaria, por exemplo, que se desenvolveu a idéia, entre alguns críticos, de que aquele seria um “contragênero" (GUILLÉN, 1971, CABO ASEGUINOLAZA, 1992:11-12), ou seja, um tipo de narrativa contrária à tradição literária vigente.

Outro elemento pertencente ao romance picaresco e que também vai contra a corrente das modalidades literárias estabelecidas na Espanha do século $\mathrm{XVI}$ é o seu tom realista. Abandonando os elementos fantásticos das novelas de cavalaria ou mesmo o bucolismo das narrativas pastoris que existiam naquele momento, o romance picaresco apresenta um realismo cortante, envolvido em questões sociais e que apresenta posições críticas, às vezes veladas, outras não, a uma sociedade em decadência.

O fato de o romance picaresco se mostrar como oposto às correntes literárias da época denota sua importância como modalidade narrativa. Ao estabelecer características contrárias a temas fantásticos ou irreais, ao apresentar um olhar crítico sobre o mundo e com isto reivindicar uma postura do leitor frente à obra literária, essa modalidade abre as portas para o surgimento do gênero romance.

O caso do Lazarillo de Tormes pode servir de ilustração para a caracterização do romance picaresco que tentamos apresentar, já que a narrativa autobiográfica, a presença marcante do pícaro como um anti-herói e sua narrativa ácida e ao mesmo tempo cômica e realista, que não deixa de apresentar, gravada em si, a imagem de uma sociedade em plena decadência, são os elementos que compõem essa forma literária. 
O Lazarillo, porém, além de ser a obra que consideramos inaugurar o gênero picaresco, apresenta uma estrutura de sentidos um pouco mais complexa do que a maioria das obras que posteriormente o seguiram. Uma série de contradições ao longo da narrativa e diferentes possibilidades de interpretação fizeram dessa pequena obra um desafio para seus leitores e para a crítica.

Apesar de sua importância, durante algum tempo, Lazarillo de Tormes foi considerado um texto inacabado graças à divisão em tratados que apresenta. Não é difícil perceber que alguns dos tratados que compõem este romance são mais desenvolvidos que outros. Com isso, fortaleceu-se a idéia de que provavelmente o romance foi entregue por seu autor à publicação ainda estando inacabado.

Essa é uma idéia defendida por alguns autores, é o caso, por exemplo, de Francisco Ayala (1971:74), que comenta:

[...]mi teoría es que, por razones ignoradas, el manuscrito del Lazarillo debió de llegar a la imprenta en un estado de elaboración incompleta.

Se trataría de un proyecto no plenamente realizado. Examinando el texto con la atención debida se advierte, en efecto, un salto demasiado brusco desde el nivel alcanzado en el capítulo tercero hasta las condiciones en que se nos dan los tres siguientes, extrañas y sin duda anómalas en relación con la pauta ya establecida en el libro por virtud de los que preceden. No olvidemos que, al ponerse a escribirlo, se aventuraba su autor a explorar un terreno literario desconocido; que era un descubridor, y por tanto debía ir modificando y alterando su plan originario de acuerdo con los hallazgos que sus intuiciones geniales le entregaban.

Considerar que Lazarillo de Tormes é um romance inacabado, talvez possa ser um julgamento precipitado. Existem vários elementos dentro da obra que comprovam a sua completude. Vejamos: Lázaro de Tormes, narrador e personagem do romance propõe narrar um "caso" a Vuestra Merced, já que isso lhe havia sido solicitado, mas antes de relatar o "caso" em questão, se dispõe a contar 
a história de sua vida. Forma-se assim, no romance, uma narrativa autobiográfica (por parte da personagem) que parte do nascimento de Lázaro até o "caso" que motiva a narração.

Ao longo do romance, tanto a história da vida de Lázaro quanto o "caso" que motiva a narrativa são contados e com isso, as propostas apresentadas pelo narrador são realizadas, a motivação interna do romance se comprova e nele não restam questões inacabadas. Abaixo temos o comentário de Francisco Rico (1988:13) sobre essa questão:

\begin{abstract}
Es moneda de curso corriente entre la crítica que "el Lazarillo es un libro inconcluso". Vale la información, desde luego, si se limita a subrayar que nos las habemos con una ficción autobiográfica, con la narración de 'una vida - escribe don Américo Castro - que, por el mero hecho de contarse, ha de permanecer necesariamente oscilante e inconclusa'. Me parece inexacta, en cambio, si implica que el Lazarillo empezó a circular y llegó a letras de molde "aun cuando el autor no lo había dado por concluido"; o si la suposición de que "nuestras tres principales novelas picarescas, el Lazarillo, el Guzmán, el Buscón, quedan constitutivamente interminadas", conduce a interpretar la primera como "desintegración... del mito del puer aeternus". De hecho, si un libro concluso, bien rematado, es el que se ha propuesto a sí mismo un asunto $\mathrm{y}$, por tanto, un término, ha desarrollado aquél hasta llegar a éste, el sintagma se aplica perfectamente al Lazarillo.
\end{abstract}

Muitos podem questionar, ainda, o fato de alguns dos tratados do romance não serem tão desenvolvidos quanto os outros, como no caso dos tratados $\mathrm{V}$ e VI, porém, a própria divisão em tratados da obra pode ser questionada. Recorrendo novamente a Rico (1988: 113-115), em um de seus estudos sobre o Lazarillo, encontramos a idéia de que provavelmente, a divisão em tratados presente no romance, não existia no manuscrito da obra, podendo ser de responsabilidade do primeiro editor da obra.

Não há como negar, também, que a própria estrutura em que é organizada a obra comprova essa teoria. Lazarillo de Tormes nos é apresentado 
como uma carta escrita a Vuestra Merced. Nela Lázaro de Tormes tem como objetivo contar um determinado "caso", e o faz. Não havia motivos para que a carta da personagem estivesse dividida em tratados, já que a carta como gênero tem uma estrutura bem diferente da estrutura de um romance ou uma novela. Uma divisão em tratados iria contra a escolha do autor pelo gênero epistolar na estrutura de sua obra. A divisão em tratados poderia ser e foi um elemento que vai contra a construção da verossimilhança da obra.

Desconsiderando a divisão da obra em tratados, Lazarillo de Tormes mostra-se como um texto completo, com uma estrutura fechada baseada na causalidade, onde não há espaço para a adição de novos episódios, tornando difícil a comprovação da idéia de que esteja inacabado.

Embora acreditemos, assim como Rico, na arbitrariedade da divisão de Lazarillo em tratados e na completude da obra, não podemos deixar de observar uma ruptura discursiva no seu prólogo. O discurso presente no prólogo da obra, que foi tido até hoje pela maioria da crítica como parte do discurso de Lázaro de Tormes, narrador e personagem do romance, conforme notou Rosa Navarro Durán (2003:13), apresenta, na verdade, dois discursos.

Navarro Durán apresenta a hipótese de que, no prólogo de Lazarillo de Tormes, podemos encontrar dois discursos, o primeiro, de seu autor anônimo e o segundo, que podemos considerar já como o início do romance, de Lázaro de Tormes. No texto, podemos identificar o discurso que consideramos ser do autor anônimo pelo trecho iniciado com "Yo por bien tengo que..." até "... y vean que vive un hombre con tantas fortunas peligros y adversidades"(p. 3 a 9) ${ }^{2}$; e o trecho onde

\footnotetext{
${ }^{2}$ Para este trabalho utilizaremos a seguinte edição de Lazarillo de Tormes: ANÔNIMO. Lazarillo de Tormes. Madrid: Cátedra, 2002.
} 
começa o discurso de Lázaro, que se inicia com "Suplico a Vuestra Merced reciba este pobre servicio..."(p.9 em diante).

Não é difícil concordar com Navarro Durán, uma vez que um estudo atento do prólogo do romance pode confirmar a sua hipótese. Se compararmos os trechos que consideramos ser do autor anônimo e de Lázaro, encontraremos algumas diferenças discursivas que comprovam a teoria de que o prólogo de Lazarillo de Tormes contém dois discursos.

Observemos o primeiro e o último parágrafo do trecho do prólogo que consideramos ser parte do discurso do autor anônimo, e o primeiro parágrafo que consideramos compor o discurso de Lázaro:

Yo por bien tengo que cosas tan señaladas, y por ventura nunca oídas ni vistas, vengan a notícia de muchos y no se entierren en la sepultura del olvido, pues podría ser que alguno que las lea halle algo que le agrade, y a los que no ahondaren tanto los deleite. (p. 3-4)

Y todo va desta manera; que confesando yo no ser más sancto que mis vecinos, desta nonada, que en grosero estilo escribo, no me pesará que hayan parte y se huelguen con ello todos los que en ella algún gusto hallaren, y vean que vive un hombre con tantas fortunas, peligros $y$ adversidades. (p.8-9)

Suplico a Vuestra Merced reciba el pobre servicio de mano de quien lo hiciera más rico, si su poder y deseo se conformaran. $Y$ pues Vuestra Merced escribe se le escriba y relate el caso muy por extenso, parescióme no tomalle por medio, sino del principio, porque se tenga entera noticia de mi persona; y también porque consideren los que heredaron nobles estados cuán poco se les debe, pues Fortuna fue con ellos parcial, y cuánto más hicieron los que siéndoles contraria, con fuerza y maña remando salieron a buen puerto. (p. 9-11)

É fácil perceber que o discurso presente nos dois primeiros trechos apresentados se dirige a um determinado público leitor, além disso, não podemos deixar de notar a presença de certa erudição. Já no caso do terceiro trecho citado, 
notamos que o discurso que apresenta já não se dirige ao público leitor, e sim a um único leitor, tratado de Vuestra Merced.

Temos assim, dois diferentes discursos no prólogo do Lazarillo: um dirigido a todo o público leitor, e outro a um único leitor. Fica clara a existência de uma ruptura discursiva neste prólogo e clara também a presença de duas diferentes vozes no romance.

A primeira voz apresentaria realmente um prólogo para a obra. A segunda já seria a voz do narrador do romance Lázaro de Tormes, dando início à sua narrativa.

Ao pensar na presença das duas vozes presentes no romance, e no fato de que durante tanto tempo não se identificou a ruptura discursiva que temos na obra, podemos imaginar uma explicação para a "união" desses dois discursos no conhecido prólogo de Lazarillo de Tormes. Como diz Mario González (2005: 203):

Da mesma maneira como os impressores fragmentaram o texto do manuscrito em 'tratados' que não existiam no original e chamaram de "Prólogo" o seu começo, cabe pensar que também podem ter fundido, nesse "Prólogo", segmentos que não estariam unidos no original. É evidente que há um corte no atual "Prólogo", no momento em que o leitor é surpreendido pela referência a "Vuestra Merced" como destinatário de um texto que, até agora, parecia dirigido simplesmente ao leitor implícito em toda narrativa escrita.

Ou seja, da mesma maneira como se criou uma divisão em tratados para o romance que provavelmente não fazia parte do texto original, podemos pensar que no trecho que conhecemos atualmente como prólogo do Lazarillo de Tormes, foram unidos dois discursos, um que possivelmente compunha o que seria o prólogo da obra, e outro que já apresentava o discurso do narrador do romance, dando-lhe início. 
Reconhecer um outro discurso no prólogo do Lazarillo é mais um fator a influenciar a leitura que se pode fazer dessa obra, já que durante muito tempo todo o texto que compõe o prólogo era creditado ao narrador da obra, Lázaro de Tormes. Ao considerar uma outra voz no prólogo do romance, nos damos conta de que nesta parte da obra podemos encontrar um discurso que não necessariamente tenha algo a ver com o discurso do narrador da obra. Percebemos que temos um ponto de vista diferente do ponto de vista do narrador, e que o diálogo estabelecido entre esses diferentes pontos de vista pode levar-nos a uma outra leitura do romance.

Considerando o discurso do prólogo da obra, e considerando também a forma como é elaborado, percebemos nele um tom erudito que em alguns momentos pode apresentar certa ironia. Temos um prólogo, como veremos mais adiante, que apresenta elementos clássicos, comuns aos prólogos que compunham as obras contemporâneas ao Lazarillo, porém escrito à sua maneira, uma vez que não deixa de recriar e satirizar os prólogos e obras da época. Sobre isso, comenta Rico (1988:58):

En el Prólogo se extrema una de las técnicas esenciales del Lazarillo: ofrecer primero unos elementos con apariencias de autonomía, de valor propio; y mostrarlos luego subordinados a un diseño mayor, mudándolos de sentido, merced a la introducción de nuevos datos.

Temos uma perversão dos valores presentes nos prólogos da época de Lazarillo em seu prólogo. Esses valores são dotados de outros sentidos, diferentes daqueles que possuíam originalmente. Porém o prólogo de Lazarillo de Tormes não deixa de cumprir com o seu papel dentro da obra: nele temos uma apresentação do romance, que pode chegar a dirigir a leitura que será feita dele. 
Além da perversão de certos valores clássicos, não podemos deixar de notar que se formam nesse prólogo algumas ambigüidades. Vejamos novamente o trecho do prólogo que inicia a obra:

\footnotetext{
Yo por bien tengo que cosas tan señaladas, y por ventura nunca oídas ni vistas, vengan a noticia de muchos y no se entierren en la sepultura del olvido, pues podría ser que alguno que las lea halle algo que le agrade, y a los que no ahondaren tanto los deleite. (p. 3-4)
}

Nesse trecho encontramos uma alusão irônica às novelas de cavalaria, gênero bastante popular na época em que o Lazarillo foi publicado. Nesse gênero literário é comum encontrar a presença de elementos fantásticos "nunca ouvidos e nem vistos", porém pode-se afirmar com certeza que estes elementos fantásticos não estão presentes no Lazarillo.

O Lazarillo de Tormes é diferente das obras de sua época, apresenta elementos novos "nunca ouvidos e nem vistos" como já dizia o seu prólogo, mas a novidade de Lazarillo está no realismo presente na obra, está em uma narrativa que apresenta a vida de um homem comum, bastante diferente dos grandes cavaleiros protagonistas das novelas de cavalaria. Lazarillo inovou a literatura espanhola ao apresentar um pícaro como narrador e protagonista de uma narrativa, inovou também ao ousar apresentar um olhar crítico sobre a época em que surgiu, inovou tanto que chegou a motivar o desenvolvimento de um novo gênero literário: o romance picaresco.

Por outro lado, se observamos novamente o trecho citado, notamos que o discurso do prólogo chama a atenção do leitor para o tipo de leitura que poderá 
fazer da obra: uma leitura superficial ou mais profunda, uma que leve ao deleite e outra que poderia levar a ponderar sobre o ponto de vista apresentado na narrativa.

O leitor já é avisado no prólogo da liberdade para fazer da obra a leitura que quiser, além do fato de poder encontrar em sua leitura algo novo, inesperado. Isso não deixa de ser verdade, pois, como vimos, o realismo presente na obra e mesmo a sua personagem principal são uma novidade na literatura do século XVI, algo para o qual o leitor desavisado não estaria preparado.

Para compor uma narrativa realista e inovadora como o Lazarillo, o seu autor teve de buscar uma estrutura que se mostrasse verossímil para o seu público, e foram justamente a autobiografia e a estrutura do romance, escrito como uma carta a Vuestra Merced, os elementos que contribuíram a criação desse realismo ao longo da narrativa.

Não podemos deixar de recordar que a publicação de cartas no século XVI fez muito sucesso, como diz Rico (1988:83):

\begin{abstract}
Desde los alrededores de 1540, por otro lado, la simiente de la epistolografía humanística estaba dando un fruto riquísimo en romance: las lettere volgari, las carte messaggiere, se habían convertido en estupendos best-sellers y suscitaban tal fervor, que incluso quienes carecían de la educación adecuada se sentían tentados a cultivar el género.
\end{abstract}

Isso foi mais um fator importante para o Lazarillo, já que com a popularidade do gênero epistolar e conseqüentemente a familiaridade do público leitor com esse tipo de publicação, sua recepção foi muito positiva. $O$ fato de o Lazarillo ser apresentado como uma carta fez com que o público o recebesse 
realmente como tal e que transferisse a ele a mesma recepção que era recebida pelas verdadeiras cartas publicadas na época.

Ainda segundo Rico (1988:77), era comum no Renascimento as cartas tratarem de um "caso", assim como era comum apresentar a biografia do autor ou a do protagonista do "caso", para que este fosse melhor interpretado.

Tanto a autobiografia quanto a carta são modalidades narrativas que se situam entre a realidade e a ficção. Há nelas aspectos criados ou recriados por seus autores e outros diretamente tomados da realidade. A utilização desses gêneros contribui para a construção de um realismo na narrativa. O leitor percebe que o que lê poderia fazer parte da realidade e a verossimilhança do texto se fortalece.

Tratando da questão da autobiografia e da verossimilhança nesse tipo de narrativa, temos o seguinte comentário de Cabo Aseguinolaza (1992:58):

Cualquier narración de forma autobiográfica tiende a ser tomada, salvo indicio o evidencia en contrario, como real e, incluso si aparece firmada por su verdadero autor, algo conduce a identificar, si no hay contradicción, a éste con el narrador. Y ello es algo de importancia en la evolución de la serie picaresca y en la propia conformación de cada una de las obras que la integran.

Com isso, podemos dizer que no Lazarillo a utilização das formas autobiográfica e epistolar é ferramenta para a construção da ficção. Lázaro de Tormes é um personagem, portanto, sua autobiografia não passa de uma ficção, de uma criação artística, assim como também a carta que escreve a Vuestra Merced é ficção. 
A adoção desses gêneros que se situam entre realidade e invenção dão à narrativa de Lazarillo um aspecto realista. $\mathrm{Na}$ época em que o livro foi escrito, tanto a autobiografia como as cartas eram escritas por pessoas reais, não por personagens como é o caso de Lázaro de Tormes, não se questionava a "verdade" e a "realidade" presente nesses gêneros.

Lazarillo de Tormes provavelmente foi considerado por alguns de seus leitores uma obra que tratava da vida de uma pessoa real. Para muitos, Lázaro de Tormes existia e ele mesmo havia escrito a carta a Vuestra Merced. Temos assim outro aspecto inovador dessa obra, a utilização da autobiografia e da forma epistolar conferiram à obra não só um perfil realista, mas também verossímil.

Não conhecemos o autor de Lazarillo de Tormes, mas talvez esse seja um outro elemento que contribua para a manutenção do realismo e da verossimilhança presentes na obra. Nas palavras de Américo Castro (1957:109):

[...]como una biografía de tan minúsculo personaje habría carecido de toda justificación (estaba muy lejos del Romanticismo del siglo XIX), el autor hubo de inhibirse y ceder la palabra a la criatura concebida en su imaginación. El estilo autobiográfico resulta así inseparable del mismo intento se sacar a la luz del arte un tema hasta entonces inadvertido o desdeñado. La persona del autor (de ascendencia judía) se retrajo tanto, que ni siquiera quiso revelar su nombre. El autobiografismo del Lazarillo es solidario a su anonimato.

Para Américo Castro, o anonimato do autor de Lazarillo é mais um elemento que contribui para a construção do sentido da obra, uma vez que nela temos uma autobiografia e o fato do autor não se revelar, confere ao discurso de Lázaro mais valor.

Maior valor tem ainda o discurso do narrador se consideramos ao lado de Rico (1988:157) que, na época em que Lazarillo foi publicado, "la norma sólo rara 
vez transgredida fue no establecer ninguna distinción entre el personaje y el novelista", ou seja, no caso do Lazarillo, sendo o seu autor anônimo, a figura do narrador como que recebe a responsabilidade pela obra. Para os leitores da época, Lázaro de Tormes, narrador e personagem, poderia facilmente ser confundido com o autor da obra, era como se Lázaro fosse realmente o autor do romance.

Não podemos negar também que o anonimato do autor de Lazarillo tenha sido uma forma de preservá-lo em uma época de muita intolerância. Com a Inquisição que estava instaurada na Espanha quando houve a primeira publicação do romance, seu autor poderia correr o risco de ser perseguido graças ao conteúdo da obra. Seu anonimato foi uma espécie de auto-proteção que não chegou a estender-se à sua obra.

A perseguição sofrida por esse romance foi motivada pelas sérias críticas que apresenta a alguns membros da Igreja, pelo fato de fazer uma paródia de toda sociedade espanhola da época, além da crítica a essa mesma sociedade que se percebe ao longo da narrativa.

Lazarillo de Tormes apresenta sérias denúncias a uma sociedade hipócrita e decadente. Lázaro, narrador e personagem do romance, apresenta-se ao fim de seu relato como uma personificação dessa sociedade. Lázaro é resultado do que aprendeu nesse meio. Não é difícil, então, compreender por que no prólogo de Lazarillo de Tormes os leitores são avisados de que nessa obra podem realizar diferentes tipos de leitura, desde as mais superficiais até as mais profundas.

A opção dada ao leitor de aprofundar ou não a leitura do romance é uma outra novidade existente no Lazarillo. A mudança de postura do leitor que antes do Lazarillo era passiva transforma-se, já que nesse romance ele também é 
responsável pela construção do sentido da obra; ele precisa interpretá-la para darIhe um sentido.

Já no Lazarillo de Tormes podemos pensar que começa a formar-se o leitor de romance, o leitor moderno, que participa da construção do sentido das obras que lê, como diz Lubbock (1976:20):

O leitor de um romance - refiro-me ao leitor crítico - é também romancista; é o fazedor de um livro que poderá agradar ou não a seu gosto quando estiver pronto, mas um livro pelo qual terá de assumir a sua quota de responsabilidade.

Lazarillo de Tormes já apresenta em seu prólogo a idéia de que não tem um sentido único, de que tal sentido deve ser conferido à obra a partir do tipo de leitura que seja feita pelo leitor, desenvolva ele uma leitura profunda ou não. Com o Lazarillo - e não podemos negar-Ihe o mérito - começa a desenvolver-se um leitor que faz escolhas, que questiona e confere sentido ao que lê, abandonando uma postura passiva e vendo-se como responsável pelas leituras que desenvolve. 


\section{CAPÍTULO 3}

\section{A VOZ DO PRÓLOGO}

O prólogo é um tipo de texto que antecede boa parte das obras literárias.

Como uma espécie de apresentação, dirige-se ao leitor e prepara-o para o que encontrará em sua leitura.

Tendo sua origem no teatro grego, o prólogo também formou parte do teatro medieval e renascentista sendo uma espécie de introdução do tema das peças que eram encenadas.

Durante a Idade Média e o Renascimento, os prólogos tornaram-se também parte integrante do discurso romanesco, sendo, como ocorria no teatro, uma prévia, uma apresentação e preparação do público leitor para o conteúdo da obra que pretendia ler.

Estudando os prólogos existentes na obra de Gil Vicente, Palma (1999:37) trata da origem dos prólogos em geral e de sua utilização no teatro através dos tempos:

As transformações e a permanência do prólogo avaliadas sinteticamente, ao longo de sua trajetória, indicam que, originalmente, na tragédia grega, ele era um discurso esclarecedor anterior a (sic) primeira aparição do coro. Eurípedes transformou-o em um monólogo que expunha a origem da ação dramática. Na Idade Média, aparece como uma exposição aclaradora dirigida ao público por um precursor, espécie de mestre de cerimônias. O teatro clássico francês e alemão recorreu ao uso do prólogo como gesto social para assegurar os favores dos príncipes, ou para dar um (sic) idéia geral da missão da arte ou do trabalho teatral. Quase desaparece, quando o teatro pretende ser uma representação realista, visto ser considerado um enquadramento desrealizante da ficção teatral. Reaparece com os dramaturgos expressionistas ou épicos, principalmente 
com Brechet em cuja obra desempenha um papel fundamental no distanciamento crítico de cunho ideológico.

A partir do que comenta Palma, percebemos que o prólogo mantém, mesmo com o passar do tempo, as suas características essenciais: introduzir e aclarar uma temática que posteriormente será apresentada em uma obra.

É novamente Palma (1999:37) que tenta definir o alcance e o papel desenvolvido pelos prólogos:

De forma geral, o prólogo é um elemento estruturalmente aclarador; a parte introdutória da obra que objetiva garantir o máximo de entendimento; recurso didático-pedagógico que na arquitetura dramática serve tanto ao Autor como ao espectador ou leitor.

É interessante pensar na questão da importância do prólogo para o autor e para o leitor ou espectador de uma obra. Sendo uma introdução à obra, o prólogo torna-se um elemento que apresenta não só a obra, mas também o olhar que tem o autor sobre ela. Além disso, a partir do prólogo também é possível identificar o tipo de leitor (ou espectador) imaginado pelo autor e que terá contato com a sua criação, ou mesmo, o tipo de leitura (ou recepção) que espera que desenvolvam dessa obra.

É como se o prólogo fosse um meio pelo qual se estabelecesse um contato entre o autor e o leitor, com esse elemento parece formar-se um laço entre quem escreve e quem lê. É o espaço onde o autor ainda tem algum controle sobre sua obra, uma vez que nesse contexto pode tentar justificar ou mesmo direcionar a atenção do leitor para aquilo que pensa ser importante em sua criação. 
Oliveira $^{4}$ diz que o prólogo:

\begin{abstract}
Fica no limiar entre o mundo do faz-de-conta e o mundo real. É o espaço onde se coloca o escritor para, como um mestre de cerimônias, introduzir o leitor. Sabe que é o último momento de que dispõe para uma conversa direta com ele, que, depois, imergirá no território da fantasia, criado, de certa forma, para ele - pois não se pode conceber, ou é muito difícil que isto aconteça, escrever-se um livro sem se pensar no leitor futuro território onde o escritor já não disporá de recursos para defender-se contra os possíveis ataques que a obra poderá sofrer: "O autor, após escrever sua obra, vê prejudicada sua individualidade pessoal porque entre ele e o leitor interpôs-se um mundo de criação artística que por sua própria força interna aniquila o escritor" (PORQUERAS MAYO, 1957, p. 140.) Portanto, o prólogo é o espaço onde o autor estende a sua mão com amabilidade ao leitor, buscando captar a sua benevolência.
\end{abstract}

Estabelecendo um contato com o leitor, o prólogo não deixa de ser um espaço para o autor defender a sua obra ou mesmo justificá-la, sendo uma espécie de apelo ao leitor que terá consigo, a partir de sua leitura, o poder de aprovar ou não a matéria que forma a obra artística.

Mas a voz desse autor que se apresenta no prólogo é, no final das contas, a voz do autor real da obra ou podemos pensar que esta é a voz do autor implícito que a compõe? Já vimos as relações estabelecidas entre o autor real e o autor implícito e sabemos que dentro de uma obra não nos encontramos com o ser real, responsável pela autoria da obra, e sim com a sua projeção: o autor implícito.

Considerando o prólogo como parte de uma obra, e considerando também o autor implícito como uma representação artística, como um alter ego do autor real que se projeta em toda a obra, podemos dizer que a voz que se

\footnotetext{
${ }^{3}$ PORQUERAS MAYO, A. El prólogo como género literario: su estudio en el siglo de oro español. Madrid: Ibarra, 1957.

${ }^{4}$ Trabalho apresentado no 3 o Colóquio do Pólo de Pesquisa sobre relações Luso-Brasileiras com o título "Alencar e Camilo: os prólogos como legitimadores do novo espaço literário", disponível em: http://www.realgabinete.com.br/coloquio/3 coloquio outubro/index.htm, acesso em 05 de junho de 2008.
} 
apresenta no prólogo e que nele apresenta o argumento da obra, demonstrando o seu ponto de vista sobre ela e também justificando-a e defendendo-a, é a do autor implícito.

O prólogo mostra-se então como mais um espaço da obra em que se manifesta o autor implícito e onde, pela primeira vez, o leitor depara-se com este elemento que é o responsável pela organização da obra, seja ela uma organização estrutural ou de sentidos.

Sendo o prólogo uma prévia da obra artística, percebemos que muitas vezes, o seu conteúdo pode não só estar relacionado à obra, mas também ao contexto externo em que ela foi criada. Comenta Palma (1999:37):

\begin{abstract}
Sendo um elemento híbrido ficcional e não ficcional, apresenta duas categorias de funções, as extratextuais e as intratextuais. As primeiras estabelecem a relação entre a criação e a sociedade, a partir da qual a linguagem dramática cumpre seu papel social. A segunda categoria de funções, as intratextuais, estabelecem a relação entre o prólogo e a ação dramática, cumprindo seu papel estrutural na armação do esquema da peça.
\end{abstract}

Nos romances o prólogo acaba por formar-se por elementos extratextuais que podem estar relacionados a questões estéticas, sociais e culturais, e pelos elementos intratextuais, aqueles relacionados à própria narrativa que precede.

Comecemos a pensar no caso do Lazarillo de Tormes. O prólogo dessa obra é, há algum tempo, considerado por boa parte da crítica uma das chaves de leitura para esse romance picaresco, uma vez que nele encontramos algumas informações que certamente podem influenciar a leitura final desse romance.

Sabemos, como vimos no primeiro capítulo, que a parte conhecida como o prólogo desse romance apresenta algumas questões que precisam ser discutidas. 
Comentamos anteriormente que a divisão do Lazarillo em tratados e mesmo a designação de prólogo para o trecho que temos no início da obra, pode não ter sido obra de seu autor anônimo, mas uma "colaboração" de seu primeiro editor. Tal consideração é imprescindível para a leitura que faremos do prólogo desse romance, uma vez que teremos que repensar os limites do prólogo original da obra e do início da narrativa.

Vimos também que há uma ruptura discursiva na parte do Lazarillo denominada "prólogo" e que observando com atenção esta parte da obra, percebemos que de seu início até um certo ponto desse trecho, encontramo-nos com um verdadeiro prólogo ao Lazarillo. Nele temos um discurso que apresenta todos os elementos que comumente encontramos em um prólogo.

No outro trecho dessa mesma parte da obra que conhecemos como prólogo de Lazarillo de Tormes, temos um outro discurso desvinculado do discurso que se apresentava até então, um discurso que já não está direcionado ao público leitor, mas a Vuestra Merced. Este é o início do discurso de Lázaro de Tormes, narrador da obra.

Desta maneira, podemos dizer que o discurso presente no prólogo de Lazarillo de Tormes, tido até hoje pela maioria da crítica como parte do discurso de Lázaro de Tormes, narrador e personagem do romance, conforme já haviam notado Rosa Navarro Durán (2003: 13) e Mario González (2005: 203), entre outros, apresenta, na verdade, dois discursos: um que pode ser atribuído ao autor implícito do romance, e outro do narrador da obra, Lázaro de Tormes.

Neste capítulo trataremos somente da parte do prólogo do Lazarillo de Tormes que realmente consideramos ser o prólogo da obra, deixando para o 
próximo capítulo o trecho que consideramos ser o início do discurso do narrador do romance.

Como já dissemos, no prólogo do Lazarillo, encontramos um prólogo que apresenta todas as características comuns a um prólogo, principalmente a um prólogo comum à época da publicação da obra. Sobre isso, diz Lázaro Carreter (1983: 172):

\begin{abstract}
La lectura rápida de este par de páginas permitiría asentir al dictamen de Ch. Ph. Wagner que en 1917, las definó como "a rather convencional prologue". En efecto, considerado con cánones estrictamente retóricos, se trata de un exordio destinado a conseguir la atención y benevolencia del público, justificar el esfuerzo y anunciar el contenido de la narración.
\end{abstract}

Sabendo que prólogo do Lazarillo apresenta elementos clássicos, próprios desse tipo de texto, não podemos ignorá-los em nossa leitura, por outro lado, acreditamos ser importante reconhecer também o ponto de vista assumido pela voz que se pronuncia nesse prólogo compreendendo qual sua posição frente ao conteúdo da obra.

O prólogo do Lazarillo é o prólogo de um autor anônimo. O fato de não conhecermos o autor real da obra é por um lado positivo, já que não nos vemos presos a uma imagem de escritor, mas isto também é relativo, pois mesmo não sabendo quem é o verdadeiro autor do Lazarillo, podemos, a partir do discurso do autor implícito da obra, reconhecer algumas características desse autor real, tais como a sua erudição e o seu olhar crítico sobre a sociedade espanhola.

Sem a imagem do autor real, no prólogo de Lazarillo temos um autor implícito com liberdade para expressar-se, livre de julgamentos que pudessem atingir o homem real que criou esse romance. A forma como se posiciona esse 
autor implícito no prólogo já anuncia o seu ponto de vista que será expresso ao longo na narrativa, já é um prenúncio do sentido da obra.

Vejamos o inicio do prólogo de Lazarillo de Tormes:

\footnotetext{
Yo por bien tengo que cosas tan señaladas, y por ventura nunca oídas ni vistas, vengan a noticia de muchos y no se entierren en la sepultura del olvido, pues podría ser que alguno que las lea halle algo que le agrade, y a los que no ahondaren tanto los deleite. (p. 3-4)
}

O prólogo se inicia com um "yo", com uma primeira pessoa que podemos identificar como a voz do autor implícito, que se sente à vontade para impor-se neste trecho da obra e que se sente autorizado a impor também neste momento o seu ponto de vista, uma vez que como já vimos, o prólogo é o espaço em que a voz do criador da obra pode mostrar-se abertamente.

Já nas palavras iniciais do prólogo temos uma exaltação à obra, que apresenta "cosas tan señaladas, y por ventura nunca oídas ni vistas", algo inédito e curioso para o leitor, algo que não pode ser esquecido e que pode instigar o leitor a conhecer a obra.

O público já é nesse momento chamado para a leitura, e mais, é informado de que tem duas possibilidades de leitura para essa obra: uma mais aprofundada e outra menos. De qualquer maneira esse leitor percebe que deverá escolher a forma como interpretará esse livro, já que o prólogo indica que esta obra não tem só um sentido.

Em uma época de sucesso das famosas novelas de cavalaria, com seus feitos nunca vistos e os acontecimentos inimagináveis que as compunham, iniciar 
um prólogo para uma obra como o Lazarillo de Tormes, dizendo que esta obra apresentará acontecimentos nunca vistos antes, é no mínimo irônico.

Lazarillo de Tormes nada tem de inimaginável, salvo o fato de contar a vida de um pícaro como Lázaro de Tormes, algo realmente inimaginável para a época da publicação da obra, quando a vida de um homem miserável nunca seria motivo para a publicação de uma obra.

Percebemos que o prólogo de Lazarillo pode ser mais que uma simples apresentação da obra, percebemos que o autor implícito aproveita esse espaço para demonstrar o seu olhar não só sobre a literatura, como também sobre a sociedade em que estava imerso.

A referência às novelas de cavalaria que depois se mostrarão, ao longo da narrativa, como opostas ao Lazarillo, além de criar um ar irônico, possibilitam uma reflexão acerca do tipo de literatura produzida na época da sua publicação, uma literatura alienada, que estava completamente desvinculada da realidade espanhola.

O Lazarillo apareceu como uma obra que refletia uma sociedade decadente, uma obra dotada de um tom realista, que chamava à reflexão e que era inovadora, daí a referência a coisas nunca ouvidas e nem vistas do início do prólogo.

Seguindo com a leitura do prólogo, encontramos algumas referências a autores clássicos e a defesa da obra para os leitores: 
cosa se debría romper ni echar a mal, si muy detestable no fuese, sino que a todos se comunicase, mayormente siendo sin perjuicio y pudiendo sacar della algún fructo.

Como sabemos, é comum encontrar nos prólogos uma defesa da obra, argumentos que demonstrem o seu valor e, aqui, não podemos deixar de perceber que ao fazer uma referência a Plínio, começa a desenvolver-se um argumento para a defesa dessa obra.

Vemo-nos frente a uma defesa que se baseia em um autor clássico. A referência a esse autor, dá mais sustentação à defesa apresentada à obra, já que, como diz o autor clássico, não há obra que não tenha nada de bom, com isso se supõe que com o Lazarillo não seria diferente.

Com a citação de Plínio, o leitor é seduzido, tenta-se convencê-lo de que a obra que tem em mãos seguramente tem algo de bom. Diz González (1994:108):

O "Prólogo" segue com um arrazoado apoiado numa citação de Plínio o Jovem - que cita, por sua vez, seu tio Plínio o Velho - para reforçar, perante o leitor menos seduzido pela novidade do assunto, a possibilidade de encontrar mais do que ele poderia supor no texto que tem entre as mãos. Tudo se dirige a conquistar o leitor, ou seja, tudo parece ser uma atitude de escritor, e não apenas de um simples narrador.

A autoridade de Plínio não deixa espaço para que se pense na possibilidade de Lazarillo de Tormes não ser uma boa obra, ou que pelo menos não tenha algo de aproveitável. O autor implícito se apóia na autoridade de um autor clássico para dar valor à obra e para seduzir o leitor.

Ao citar um autor clássico, o autor implícito aproveita-se da situação também para mostrar erudição. O fato de possuir erudição, de mostrar conhecer os 
clássicos faz com que o autor implícito adquira também autoridade. Ele demonstra ter conhecimento suficiente para apresentar e defender essa obra.

Mais adiante no prólogo encontramos outra citação de um autor clássico:

Porque si así no fuese, muy pocos escribirían para uno solo, pues no se hace sin trabajo, y quieren, ya que lo pasan, ser recompensados, no con dineros, mas con que vean y lean sus obras, y si hay de qué, se las alaben. Y a este propósito dice Tulio: "La honra cría las artes."

Aqui a citação de Túlio, ou melhor, Marcus Tullius Cícero, mais conhecido como Cícero, tem outra função: valorizar o trabalho do escritor. Essa parte do prólogo se inicia com a idéia de que os escritores se propõem a escrever para o público, esperando que seu trabalho seja reconhecido e recompensado por elogios, já que no fato de criar e de fazer ser conhecida a sua obra, está implicada a sua honra.

"La honra cría las artes" é a citação feita de Cícero, somente com honra e somente os homens honrados podem criar as artes. Essa afirmação é importante se considerarmos a importância que tinha a honra para a sociedade espanhola do século XVI.

A honra era um dos mais altos valores dessa sociedade, ser honrado significava ser um homem de bem, um homem de valor, assim, conseqüentemente, as artes estavam associadas aos grandes homens. Ser um artista, fazer arte, era algo que competia a poucos, daí o desejo de reconhecimento presente no prólogo, e comum aos prólogos da época. O artista desejava ser reconhecido por sua criação e com isso ser reconhecido como um homem honrado. 
Mostrando-se como um artista, o autor implícito de Lazarillo também se mostra como um homem honrado, conquistando mais uma vez a simpatia e a confiança do leitor.

O desejo de elogios segue sendo apresentado ao leitor nos trechos seguintes do prólogo:

\begin{abstract}
¿Quién piensa que el soldado que es primero del escala, tiene más aborrecido el vivir? No, por cierto; mas el deseo de alabanza le hace ponerse en peligro; y así, en las artes y letras es lo mesmo. Predica muy bien el presentado, y es hombre que desea mucho el provecho de las ánimas; mas pregunten a su merced si le pesa cuando le dicen: "¡Oh, qué maravillosamente lo ha hecho vuestra reverencia!" Justó muy ruinmente el señor don Fulano, y dio el sayete de armas al truhán, porque le loaba de haber llevado muy buenas lanzas. ¿Qué hiciera si fuera verdad?
\end{abstract}

A imagem do soldado que era o primeiro da escala e o seu desejo de ser elogiado mostra a vontade de um homem de superar-se cada vez mais a troco de ver seu desejo saciado. Rico (1988:63) comenta que o tema do soldado era comum a textos dos séculos XV e XVI, e que sempre apresentava a idéia de superação, de que um homem se colocasse em perigo pelo desejo de ser reconhecido por isso.

Ainda no trecho citado temos uma referência a "Don Fulano", sobre a qual diz Rico (1988:66):

Lázaro ejemplifica cuanto puede "el deseo de "alabanza" con un tercero y último caso (aparte el propio): "Justó muy ruinmente el señor don Fulano, y dio el sayete de armas al truhán porque le loaba de haber llevado muy buenas lanzas: ¿qué hiciera si fuera verdad?" El uso de recompensar en el pronto a bufones y juglares con alguna de las prendas que se llevan vestidas es familiar a los historiadores de la literatura. Mas no se ha atendido a un dato harto significativo para el Lazarillo: la ética cristiana se detuvo a reprobar y aun a ridicularizar tal proceder y la fama vacía que con él se ganaba. 
No caso do exemplo de "Don Fulano", temos, como explica Rico, um caso de desejo de reconhecimento que funciona às avessas: ao fazer uso da tradição de presentear alguns grupos de pessoas (grupos de classe social inferior) com peças de vestimenta própria, esse "Don Fulano" cai fatalmente em uma situação de reprovação segundo a ética cristã de então, e pode-se dizer que, em suma, um ato que deveria atrair louvores tem exatamente o efeito contrário.

O último exemplo do desejo de reconhecimento, de elogios citado no prólogo do Lazarillo acaba por demonstrar a fragilidade da situação em que se encontra o artista.

Mas por outro lado, podemos entender também que o desejo de reconhecimento, tão comum aos prólogos da época, pode muitas vezes beirar o ridículo e tornar-se motivo de riso. Como um apelo exagerado, o tema do reconhecimento do artista é representado pelo autor implícito como algo pedante e cômico.

Fica claro o olhar crítico que se pousa sobre o tema, o autor implícito desenvolve um raciocínio que vai desde a citação de um autor clássico, portanto uma autoridade, até o exemplo do soldado que se supera esperando algum reconhecimento (como um lugar comum da época), até chegar a um caso em que o desejo de reconhecimento, de ser elogiado excede o bom senso e se transforma em algo grotesco.

Mantendo então o tema do desejo de reconhecimento, termina o prólogo com as seguintes palavras: 
que hayan parte y se huelguen con ello todos los que en ella algún gusto hallaren, y vean que vive un hombre con tantas fortunas, peligros y adversidades.

No último trecho do prólogo encontramos uma retomada do desejo de reconhecimento, mas neste caso, percebemos que esse desejo está subordinado a pelo menos duas questões.

A primeira é o fato de o autor implícito declarar-se como alguém que não é mais santo seus que seus vizinhos, ou seja, ele é igual aos outros homens, aos outros artistas, nem melhor e nem pior. Porém a questão é: como são esses homens a quem se compara essa voz? Podem ser honrados ou não, principalmente se levarmos em conta o exemplo citado de "Don Fulano".

Essa fala do autor implícito é ambígua. O leitor deve escolher entre as imagens apresentadas antes para caracterizar e mesmo confiar na voz que o guia pelo prólogo.

O leitor é novamente instigado a dar sentido ao que lê. Se no início do prólogo foi avisado de que esse livro poderia ter mais de uma leitura, agora é levado a decidir se pode ou não confiar na voz que o guiou por todo esse texto.

Esse prólogo é uma prévia do que o leitor encontrará no Lazarillo, já que no decorrer de sua leitura, e principalmente no desfecho do romance, terá de escolher uma posição frente ao discurso de Lázaro, terá de escolher entre confiar em suas palavras ou não, construindo assim o sentido da obra.

Uma outra questão a qual está subordinado o desejo de reconhecimento do autor implícito é o fato de apresentar sua obra como uma "nonada", como algo sem valor. 
Depois de iniciar o prólogo exaltando as qualidades da obra e de expressar seu desejo de reconhecimento com ela, o autor implícito o termina desqualificando o que já havia apresentado antes. Essa pode ser uma tentativa de expressar a sua humildade frente ao público leitor que é quem avaliará realmente a obra.

Por outro lado, ao descrever a sua obra como uma "nonada", percebemos que o autor implícito ironiza toda uma situação. Ele primeiro exalta a sua obra, descreve o seu desejo de reconhecimento para depois desqualificá-la.

Podemos pensar também que com a desconstrução do prólogo em poucas palavras, o autor implícito pode estar tentando indicar algo ao seu leitor: que essa obra possa ter algo de contraditório, tal qual o seu prólogo.

O prólogo do Lazarillo vai além da simples apresentação da obra ou de uma reprodução de temas comuns aos prólogos de uma época. Neste prólogo, encontramos uma chamada ao leitor, que tem de escolher a interpretação que dará, não só ao prólogo, como também à obra.

Há algo mais neste último trecho do prólogo que não podemos deixar de notar: o autor implícito diz que o Lazarillo foi escrito em um "grosero estilo", o estilo de obras não ficcionais, relacionados a narrativas históricas, por exemplo. Ao apresentar esse romance como escrito em "grosero estilo", temos uma preparação do leitor para o tipo de narrativa presente no Lazarillo, que longe de apresentar elementos fantásticos, está mais voltada para a realidade histórica.

Isso nos faz pensar no tipo de leitor imaginado para essa obra, pensar em qual é o leitor implícito de Lazarillo de Tormes. 
No início do prólogo, com a referência às novelas de cavalaria, imaginamos que o público que teria acesso a essa obra na ocasião de sua publicação seria um público leitor já acostumado a este tipo de obra literária e que provavelmente reconheceria no início do prólogo a apresentação do tema de elementos inimagináveis apresentados.

É claro que o leitor, ao se deparar com o prólogo, ainda não tem consciência de que a obra que tem em mãos é o oposto de uma novela de cavalaria. Somente com o decorrer da leitura se dará conta de que Lázaro não é um herói e que a referência a "coisas nunca vistas e nem ouvidas" do início do prólogo tratava de apresentar uma narrativa diferente das que faziam sucesso na época. Somente a partir de sua leitura, se dará conta de que a novidade do Lazarillo era contar a vida de um homem comum, não de um grande herói.

Percebemos então que o leitor do Lazarillo deveria ser atento e crítico para compreender algumas ironias o livro, mas não só isso, esse leitor também poderia escolher o tipo de leitura que teria da obra, mais ou menos superficial, uma leitura agradável ou deleitosa, como indica o prólogo.

Esse leitor deveria estar acostumado à leitura, a ponto de reconhecer os elementos clássicos de um prólogo, dentre eles, o desejo de reconhecimento e de elogios do autor pelo seu trabalho artístico, mas esse leitor, mais do que reconhecer esses elementos, deveria compreender o jogo de contradições que estão estabelecidas ao longo dos exemplos relacionados a esse tema no prólogo.

O leitor do Lazarillo, atento ao prólogo, estaria preparado para as contradições que aparecem na narrativa de Lázaro, uma vez que já teria lidado com outra série de contradições no prólogo da obra. Ele já saberia da importância de 
sua participação na construção do sentido da obra, uma vez que após a leitura do prólogo teria de escolher o tipo de leitura que faria da narrativa.

Consideramos que o prólogo do Lazarillo realmente é uma das chaves de leitura da obra, porque nele temos já apresentadas ao leitor, de forma irônica, algumas contradições. Estas contradições fazem com que o leitor pense na natureza da obra e mesmo no fato de que talvez a voz do autor implícito presente ao longo do prólogo (e mesmo da narrativa), não seja confiável.

Esse autor implícito que se faz conhecer no prólogo expressa claramente uma imagem contraditória, mas que contribui consideravelmente para a leitura da obra. Ele abdica do lugar de autoridade da obra, de quem leva consigo todo o sentido de sua criação e divide com o leitor a responsabilidade pela construção do sentido da obra. 


\section{CAPÍTULO 4}

\section{A VOZ DE LÁZARO}

1. Uma carta a Vuestra Merced

Lazarillo de Tormes é um romance que se apresenta na forma de uma carta. Lázaro de Tormes, narrador e personagem da história escreve uma carta a Vuestra Merced a fim de explicar-Ihe um determinado "caso", conforme essa pessoa Ihe havia solicitado anteriormente.

Acontece que Lázaro não conta imediatamente em sua carta o "caso" que a motivou. Antes de revelar o assunto de que quer tomar conhecimento Vuestra Merced, Lázaro propõe-se a contar a história de sua vida.

Dessa maneira, a carta de Lázaro torna-se também uma espécie de autobiografia, sua vida é revelada desde o seu nascimento até o momento de sua vida em que escreve a carta, momento este em que se desenvolve o "caso" que deve ser relatado ao seu destinatário.

O fato de ser uma carta, e ainda mais, uma carta autobiográfica, faz com que pensemos na importância que essas formas assumem para a construção dos sentidos desse romance.

Tanto a carta como a autobiografia podem ser designadas como formas híbridas, ou seja, são formas literárias que se colocam entre a ficção e a realidade. Em uma carta ou em uma autobiografia, temos fatos que partem da realidade, mas 
que podem ser reconstruídos no momento em que são representados em forma narrativa.

A subjetividade é uma das principais características dessas formas literárias, visto que a realidade que se supõe nelas é antes filtrada pelas impressões de quem escreve. O narrador presente nas cartas e nas autobiografias sempre é um narrador em primeira pessoa, um narrador protagonista, envolvido com o que conta e, portanto subjetivo em sua narrativa.

No Lazarillo temos um narrador completamente comprometido com o que narra. Lázaro é um narrador que se propõe a contar a sua vida e, com isso, mostrase também como um narrador subjetivo. Sendo o conteúdo de sua narrativa a sua própria vida, não há a possibilidade de narrá-la objetivamente; tudo o que conta Lázaro é pessoal, fruto de suas experiências e avaliado por ele mesmo no momento em que apresenta a narrativa.

A autobiografia e a carta assumem também um importante papel, se pensarmos na recepção da obra. Tais formas literárias, estando relacionadas a um "eu" que narra vivências próprias, atingem o público leitor de uma maneira singular, já que além de despertarem a curiosidade do leitor, também desenvolvem uma simpatia grande entre quem lê e aquela voz que se apresenta na narrativa.

Tratando da questão da recepção da carta como forma narrativa, comenta Kayser (1961:264):

Por lo demás, a esta forma narrativa se le ha atribuido carácter dramático porque en ella se establece contacto directo entre el lector y la realidad poética. Pero, sobre todo, la narración en primera persona robustece la impresión de autenticidad que ya la narración enmarcada confiere de suyo a lo narrado. 
Frente a cartas ou autobiografias, o leitor avalia como reais os acontecimentos e impressões narrados pelo narrador presente nessas formas. Ele não questiona o que encontra e sente-se próximo da voz que o leva ao longo da narrativa. Pensando especificamente no caso do Lazarillo de Tormes, Claudio Guillén (1957:268) definiu este romance como uma "epístola hablada":

\begin{abstract}
Es el Lazarillo, en primer lugar, una epístola hablada. Se dirige el narrador o personaje central de la obra a un "vuestra meced", a una personalidad de rango superior al suyo, de que sólo sabemos que es el protector de su protector, el "amigo" del Arcipreste de San Salvador: "En este tiempo, viendo mi habilidad y buen vivir, teniendo noticia de mi persona, el señor Arcipreste de San Salvador, mi señor, y servidor y amigo de vuestra merced, porque le pregonaba sus vinos, procuró casarme con una criada suya".Digo que se trata de una epístola "hablada", con términos algo contradictorios, porque parece que escuchamos, de hurtadillas, la confesión dirigida por Lázaro al amigo de su protector. Cierto que en los primeros párrafos del prólogo el autor, con no poco orgullo, manifiesta el propósito de "que cosas tan señaladas, y por ventura nunca oídas ni vistas, vengan a notícia de muchos..." Mas la confesión pública de Lázaro, cuando pasamos del prólogo al relato propiamente dicho, tiene por oyente, no al lector, sino a la persona que ha solicitado tal relato: "y pues vuestra merced escribe se le escriba y relate el caso muy por extenso, etc." La redacción del Lazarillo es ante todo un acto de obediencia.
\end{abstract}

É interessante a definição de Guillén "epístola hablada”, principalmente se consideramos que em uma carta, por mais que estejamos frente a um texto escrito, temos um "eu" que se dirige a alguém para contar algo. Esse procedimento pessoal das cartas se reproduz no Lazarillo causando a impressão de que Lázaro realmente escreve a alguém e conta-lhe algo muito pessoal: a história de sua vida. Como diz Guillén, é como se no papel de leitores, escutássemos a história de Lázaro vinda de seus próprios lábios.

Porém, não podemos nos esquecer de que Lázaro de Tormes é uma personagem fictícia, uma criação literária e que a sua autobiografia e mesmo a sua carta, fazem parte de uma criação, existem para um fim dentro da obra literária. 
A autobiografia de Lázaro não é real, não é escrita por alguém que tem recordações e que parte da realidade para expressar-se artisticamente, a autobiografia de Lázaro é fictícia, assim como a própria personagem. Isso não quer dizer, porém, que devamos ignorar o fato do discurso desse narrador se apresentar na forma autobiográfica e que deixemos de reconhecer algumas das características dessa forma narrativa para interpretar o discurso de Lázaro de Tormes.

Parece-nos interessante apresentar aqui a definição de autobiografia de Todorov (1980:57) para pensar em algumas questões referentes à autobiografia de Lázaro:

\begin{abstract}
Para falar com simplicidade, a autobiografia define-se por duas identidades: a do autor com o narrador e a do narrador com a personagem principal. Esta segunda identidade é evidente: é a que resume o prefixo "auto-" e que permite distinguir a autobiografia da biografia ou das memórias. A primeira é mais sutil: separa a autobiografia (exatamente como a biografia e as memórias) do romance, mesmo que este seja impregnado de elementos inspirados na vida do autor. Essa identidade separa, em suma, todos os gêneros "referenciais" ou "históricos" de todos os gêneros "ficcionais": a realidade do referente é claramente indicada, uma vez que se trata do próprio autor do livro, pessoa inscrita no registro civil de sua cidade natal.
\end{abstract}

Todorov levanta duas particularidades da autobiografia: a relação entre o autor e o narrador e a relação do narrador com a personagem principal de uma obra, questões importantes para o nosso estudo.

Sabemos que a autobiografia de Lázaro de Tormes é ficcional, assim, não nos interessa pensar na primeira relação apresentada por Todorov, a relação entre o autor e o narrador, uma vez que Lázaro não é um autor real, não é como diz Todorov uma "pessoa inscrita no registro civil de sua cidade natal". 
A segunda relação apresentada por Todorov, parece-nos importante para a compreensão do Lazarillo de Tormes. A relação entre o narrador e a personagem em uma autobiografia é algo que deve ser levado em consideração, principalmente se pensarmos que em meio a essa relação, está envolvida também uma questão temporal.

Comecemos a pensar na estrutura temporal do Lazarillo. Temos nessa obra um narrador conduzindo a narrativa a partir de um tempo presente, ou seja, a partir do momento em que escreve a carta a Vuestra Merced, mas que se reporta ao tempo passado para contar a sua história, assim, do momento em que narra, cria um deslocamento temporal até o passado, até sua infância seguindo uma seqüência cronológica até o momento presente, de onde narra.

Encontramo-nos então com dois Lázaros ao longo da narrativa: um que se encontra em tempo presente escrevendo a carta, e outro Lázaro que, ainda em sua infância, é personagem das lembranças do Lázaro adulto, do narrador do romance.

A narrativa começa e termina em tempo presente, é um ciclo fechado. Mas dentro desse ciclo, temos o passado do narrador, que parte da sua infância até o momento em que narra a sua história. Ambos são o mesmo, mas em tempos diferentes.

\section{LÁZARO COMO NARRADOR E COMO PERSONAGEM}

Lázaro de Tormes narra a sua história desde o seu nascimento até o momento em que se encontra escrevendo a carta a Vuestra Merced para explicar- 
Ihe um "caso". A história de sua vida não é propriamente uma história de glórias, mas ainda assim é para o narrador um exemplo de crescimento, como ele mesmo diz no início de sua narrativa:

\begin{abstract}
$Y$ pues Vuestra Merced escribe se le escriba y relate el caso muy por extenso, parecióme no tomalle por el medio, sino del principio, porque se tenga entera noticia de mi persona; y también porque consideren los que heredaron nobles estados cuán poco se les debe, pues Fortuna fue con ellos parcial, y cuánto más hicieron los que, siéndoles contraria, con fuerza y maña remando salieron a buen puerto. (p. 10,11)
\end{abstract}

Lázaro é uma personagem de origem pobre e que tenta, ao longo de sua vida, alcançar um crescimento social. O problema é que ele vive em uma sociedade na qual não existe a possibilidade de crescimento social algum, salvo nos casos de alguém que tivesse o interesse de ingressar na Igreja, tentasse a sorte nas colônias espanholas, ou conseguisse alcançar um oficio real.

A sociedade em que vive Lázaro é também corrompida moralmente e a personagem percebe, muito jovem ainda, que pode contar somente com a sua astúcia para sobreviver e alcançar os seus objetivos. Burlando-se das pessoas e situações que vive e aprendendo com suas experiências, pouco a pouco a personagem chega ao que considera ser a prosperidade, como diz nas últimas palavras de seu relato.

A narrativa desenvolvida por Lázaro se inicia com o seu nascimento e, depois de algum tempo, com a separação de sua mãe, momento no qual se dá conta de que é responsável por si mesmo. A narrativa continua com o relato de suas experiências com os amos a quem serviu e termina no momento em que Lázaro acredita viver a sua prosperidade, quando também vivencia o "caso" descrito na carta que escreve a Vuestra Merced. 
Como personagem, percebemos que Lázaro apresentava em sua infância, um olhar crítico em relação à sociedade que o cercava, porém esse olhar crítico vai se dissipando conforme a personagem vai aproximando-se do momento em que se encontra narrando sua história.

Como narrador, percebemos que Lázaro não só narra, como também deixa escapar alguns comentários críticos relacionados àquelas situações que viveu no passado, mas não critica o seu momento presente.

Mario González (1994:122), ao tratar do narrador em Lazarillo de Tormes, percebeu que é possível identificar três tipos de frases recorrentes no discurso de Lázaro, as quais ele classifica como frases de tipo "a", "b" e "c":

a) aquelas relativas ao passado narrado por Lázaro, identificadas no tempo do enunciado;

b) aquelas que são citações do pensamento de Lázaro-personagem, que, na edição aqui utilizada, vão sistematicamente colocadas entre aspas e que pertencem igualmente ao tempo do enunciado;

c) aquelas que - no tempo presente se referem claramente ao tempo da enunciação. Fora numerosos verba dicendi ou similares, que servem apenas para introduzir seqüências que correspondem ao tipo "a", as frases do tipo "c" merecem especial atenção, porque nelas aparecem as contradições que nos permitem separar a personagem literária do autor da suposta "carta".

Dando atenção à classificação feita por González, perceberemos que, com exceção das frases de tipo "a", que são aquelas que se desenvolvem no tempo do enunciado e que dão seqüência à narrativa, o estudo das frases de tipo "b" e "c" pode colaborar substancialmente para a interpretação do narrador Lázaro de Tormes.

Reconhecer as frases que reproduzem os pensamentos de Lázaro como personagem e os comentários de Lázaro como narrador permite que 
compreendamos melhor a relação estabelecida entre narrador e personagem desse romance.

\subsection{LÁZARO E SEUS PENSAMENTOS}

Neste momento, pensaremos em Lázaro de Tormes somente como a personagem protagonista do Lazarillo, desconsideraremos, por enquanto, o fato de que Lázaro é também o narrador de sua história.

Durante a narrativa, encontramos alguns enunciados que representam os pensamentos de Lázaro como personagem. Como vimos, essas são as frases de tipo “b”, catalogadas por Mario González (1994:122).

Lázaro expressa, a partir de seus pensamentos, uma visão crítica da realidade em que vive, mas esses pensamentos não estão presentes em toda a obra; eles são mais recorrentes nos períodos de infância e adolescência da personagem, nos tratados ${ }^{5} \mathrm{I}, \mathrm{II}$, III e V, desaparecendo por completo nos últimos tratados.

No primeiro tratado da obra, temos descrita a origem de Lázaro, seu nascimento e a história de seus pais, temos também o seu nascimento para a vida, o momento em que começa a servir o seu primeiro amo, um cego, quando se dá conta de que se encontra só no mundo, sendo responsável por si mesmo.

Lázaro, como vimos, tem uma origem pobre e, ainda muito jovem, perde o seu pai. Com a morte de seu pai, sua mãe tenta ganhar a vida para mantê-los, a

\footnotetext{
${ }^{5}$ Ainda que consideremos a divisão da obra em tratados arbitrária, utilizaremos tal divisão para que localizar mais facilmente no texto os trechos citados.
} 
ele e a ela, mas nem sempre isso acontecia de uma forma muito honrada para a época.

Em um determinado momento, Antona Pérez, mãe de Lázaro, começa um relacionamento com um homem de origem moura e tem com ele um outro filho. Nesse momento encontramos o primeiro pensamento expresso por Lázaro.

Ainda na "simpleza en que, como niño, dormido estaba"(p.23), ao ver que seu irmão menor, moreno, se assusta com a aparência de seu pai, que é negro, e, portanto, diferente das outras pessoas que o cercam, como sua mãe e irmão, pensa Lázaro:

"iCuántos debe de haber en el mundo que huyen de otros porque no se veen a sí mesmos!” (p. 18)

Esse pensamento de Lázaro é de certa forma muito complexo para uma criança, como era o caso da personagem naquele momento. É no mínimo contraditório que uma criança que se diz até então adormecida, e que nunca havia se afastado da mãe, consiga formular esse tipo de pensamento, consiga pensar na possibilidade de existir no mundo pessoas que não têm consciência de quem ou como são.

Uma série de contradições como, por exemplo, a presente nesse pensamento de Lázaro, vão se apresentando ao longo da narrativa; algumas apresentam-se nos pensamentos de Lázaro como vimos agora, outras em situações diferentes. Mais adiante trataremos de tais contradições.

O segundo pensamento de Lázaro-personagem neste tratado acontece imediatamente após o episódio da "cornada", quando o primeiro amo de Lázaro, o 
cego, engana-o a fim do jovem perceber que precisava ser astuto para se manter como guia de cego. O pensamento que tem Lázaro neste momento norteará as suas atitudes até o final da narrativa:

"Verdad dice éste, que me cumple avivar el ojo y avisar, pues solo soy, y pensar cómo me sepa valer." (p. 23)

Lázaro após a "cornada" se vê como responsável por si mesmo, por sua sobrevivência, percebe que cabe somente a ele defender-se do que the possa acontecer pelo caminho.

Durante o segundo tratado, Lázaro tem como amo um clérigo. Sendo a vida com esse amo mais penosa do que a anterior, com o cego, e sendo a fome, neste momento, o seu maior obstáculo, encontramos nos pensamentos da personagem freqüentes alusões à fome sofrida.

Não é difícil notar, também, a freqüente alusão a Deus nos pensamentos da personagem nesse tratado. Dos sete pensamentos expressos por Lázaro, quatro fazem referência direta a Deus, ou a santos católicos, e outro tem no contexto em que é expresso uma referência a Ele.

Servindo a um clérigo, Lázaro começa a conhecer bem de perto a vida dos "homens de Deus", percebe o quanto são distantes o discurso religioso e a vida cotidiana dos representantes da Igreja que conhece.

Denunciando essa realidade, os apelos de Lázaro a Deus mostram-se muitas vezes irônicos. Deus se torna uma espécie de cúmplice da personagem em suas peripécias, ou como diz Rodríguez Puértolas (1981:271): 
Dios es, pues, invocado por el héroe, y le ilumina, en los momentos decisivos de su vida, una vida que sabemos muy bien cómo es, qué curso sigue y cómo termina. Un Dios que aparece así al mismo nivel que el resto de los mitos establecidos, y tan cosificado, a fin de cuentas, como el mismo Lázaro de Tormes es cosificado por los demás.

A relação de Lázaro com Deus é uma relação que se estabelece por necessidade, Deus é mais que um mito para Lázaro: é aquele a quem pode apelar, já que no meio em que vive não tem alguém que esteja a seu lado.

Deus é, para Lázaro, um aliado. Percebemos tal "cumplicidade" pelo comentário da personagem na ocasião em que bateu à porta do clérigo um caldeireiro, esse foi visto por Lázaro como "un ángel enviado a mí por la mano de Dios en aquél hábito"(p. 55).

A ironia é a melhor arma de que dispõe a personagem para denunciar a realidade hipócrita percebida à sua volta. Lázaro não pode dizer explicitamente o que pensa, e é em seus pensamentos que encontramos a sua avaliação da situação a que é submetido.

Não tendo a quem dirigir o que pensa, é a Deus que dirige Lázaro um desabafo:

\begin{abstract}
"iOh Señor mío - dije yo entonces -, a cuánta miseria y fortuna y desastres estamos puestos los nascidos y cuán poco turan los placeres de esta nuestra trabajosa vida! Heme aquí que pensaba con este pobre y triste remedio remediar y pasar mi laceria y estaba yacuando que alegre y de buena ventura. Mas no quiso mi desdicha, despertando a este lacerado de mi amo y poniéndole más diligencia de la que él de suyo se tenía (pues los míseros, por la mayor parte, nunca de aquélla carecen), agora, cerrando los agujeros del arca, cierrase la puerta a mi consuelo y la abriese a mis trabajos." (p. 60)
\end{abstract}

Em um desabafo algo pessimista, Lázaro demonstra ter consciência da vida hipócrita que vive o clérigo. Uma vida de mentiras, em que o dito não é o que 
se pratica, onde um homem guarda para si privilégios que não deveria guardar e onde nem todos são iguais.

No segundo tratado podemos encontrar também uma demonstração da “maña” da qual fala o narrador no início de sua narrativa (p. 11): é a sua esperteza que Ihe garante a sobrevivência, assim, a certa altura da narrativa, encontramos Lázaro na situação de que tendo em mãos a chave da arca do clérigo, sabe que não pode saciar totalmente sua fome, pois logo seria descoberto, e pensa:

"Este arquetón es viejo y grande y roto por algunas partes, aunque pequeños agujeros. Puédese pensar que ratones, entrando en él hacen daño a este pan. Sacarlo entero no es cosa conveniente, porque verá la falta el que en tanta me hace vivir. Esto bien se sufre." (p. 59)

Somente com a sua esperteza, com a sua "maña", Lázaro é capaz de sobreviver. O rapaz resolve viver de migalhas para que o clérigo não perceba que ele estava roubando pedaços de alimentos de sua arca. Com o roubo das migalhas, o clérigo poderia suspeitar da existência de ratos em sua casa, mas não suspeitaria das ações de Lázaro.

Uma situação diferente da que vive ao lado do clérigo, é a que vive Lázaro, junto ao seu terceiro amo, o escudeiro.

No terceiro tratado encontramos o maior número de pensamentos de Lázaro-personagem, um total de onze.

Dos amos que até então teve Lázaro, o escudeiro, apesar da aparência que ostenta, é o mais miserável. Ao conhecê-lo, Lázaro se nega a crer na realidade que se Ihe apresenta, quer acreditar que com o escudeiro terá um amo abastado, 
mas lentamente se dá conta de que seu novo amo nada tem a lhe oferecer, que o escudeiro não vivia uma realidade muito diferente da dele.

A maior parte dos pensamentos de Lázaro neste tratado diz respeito, novamente, à comida, ou à falta dela, mas essa não é a única questão que toma conta dos pensamentos da personagem, agora a questão da aparência também os povoa.

Nos pensamentos relacionados à comida, a fome ainda é um fator motivador, mas agora Lázaro se depara com mais uma adversidade: além da dificuldade para alimentar-se, a personagem também deve alimentar ao seu amo.

Grande parte dos pensamentos da personagem relacionados à comida é mais uma vez dotada de ironia. A ironia não está somente no fato do servo se ver obrigado a prover a alimentação de seu amo, mas no fato do escudeiro não assumir a condição miserável em que vive, na qual é incapaz de cuidar de si e mesmo de sua alimentação.

Por um momento, Lázaro e o escudeiro vivem um jogo de aparências. O escudeiro finge viver uma vida perfeita, de homem de bem, enquanto Lázaro finge não ver o fingimento de seu amo, e finge não perceber que o está alimentando.

Assim, em um momento em que Lázaro está se alimentando, ouve do escudeiro comentários que elogiam a fome e a "graça" com que comia, como uma desculpa para poder também alimentar-se com o seu servo. Vejamos a situação em que Lázaro expressa um de seus pensamentos: tenga. 
"La muy buena que tú tienes - dije yo entre mí - te hace parecer la mía hermosa". (p. 89 - grifo meu)

O escudeiro tenta persuadir Lázaro com elogios, mas a personagem já conhecia a situação em que se encontrava o seu pobre amo. Lázaro mantém por um tempo o jogo de aparências que estava estabelecido entre eles, mas logo esse jogo é desfeito.

Lázaro alimenta o escudeiro com o produto de suas mendicâncias, mas tem de tomar cuidado para ninguém saber que vive com o escudeiro. Ambos têm consciência da miséria em que vivem, já não precisam manter um jogo de aparências dentro de casa, mas isso não significa que um jogo de aparências não se mantenha fora de casa.

Lázaro mantém o jogo do escudeiro para o mundo. O alimenta com o que consegue pedindo nas ruas, mas ninguém sabe que o escudeiro é seu amo ou mesmo que vive em condições tão difíceis. Para o resto do mundo, o escudeiro é aquilo que parece ser: um homem de bem, um homem próspero.

Mesmo com a situação em que vive com o escudeiro, Lázaro não nutre pelo seu terceiro amo sentimentos negativos, na verdade, sente pena dele e, frente a essa nova situação, consegue perceber a realidade de aparências na qual está fundada a vida de toda uma sociedade:

"iBendito seáis Vós, Señor - quedé yo diciendo - , que dais la enfermedad y ponéis el remedio. ¿Quién encontrará a aquel mi señor que no piense, según él contento de sí lleva, haber anoche bien cenado y dormido en buena cama, y, aun agora es de mañana, no le cuenten por muy bien almorzado? ¡Grandes secretos son, Señor, los que Vós hacéis y las gentes ignoran! ¿A quién no engañará aquella buena disposición y razonable capa y sayo? ¿Y quién pensará que aquel gentil hombre se pasó ayer todo el día sin comer, con aquel mendrugo de pan que su criado Lázaro trujo un día y una noche en el arca de su seno, do no se le 
podía pegar mucha limpieza, y hoy, lavándose las manos y cara, a falta de paño de manos se hacía servir de la halda del sayo? Nadie, por cierto, lo sospechará. ¡Oh, Señor, y cuántos de aquestos debéis Vós tener por el mundo derramados, que padescen por la negra que llaman honra lo que por Vós no sufrirán!" (p. 83)

É novamente a Deus a quem Lázaro dirige o seu desabafo e novamente é um pensamento pessimista da personagem que se manifesta. Lázaro tem consciência de que a aparência e mesmo a honra sempre almejadas e defendidas por toda uma sociedade, pouco têm de real. A imagem que ostenta o escudeiro e que faz com que tantas pessoas o respeitem, não é capaz de dar-lhe uma vida confortável, não é capaz, ao menos, de saciar-lhe a fome.

A fome, comum a Lázaro e ao escudeiro, aproxima-os. É pela fome que sofrem ambos, que desabrocha a compaixão que Lázaro sente pelo seu terceiro amo que, ao contrário dos outros que teve, não tem nada a oferecer, nem mesmo pode manter-se por si só. Diz Jaén (1968:131):

poco a poco empieza a descubrirse la verdad completa de la miseria del escudero, víctima de la fortuna, en cierto sentido, lo mismo que Lazarillo, y así mismo va cambiando la actitud de éste, revelándonos una faceta de su carácter que, con sus amos anteriores, no había tenido ocasión o motivo de revelarse.

Mas esse é o único momento da trama em que Lázaro expressa tal tipo de sentimento. Após o abandono do escudeiro, Lázaro segue com sua vida e tem, como quarto amo, um frade das Mercês. Neste tratado (IV), porém, a personagem não expressa nenhum pensamento crítico em relação ao que vive. 
No quinto tratado, quando tem como amo um buleiro, Lázaro expressa o seu último pensamento, que já não trata da questão da fome que até então motivara grande parte dos pensamentos da personagem.

No decorrer desse tratado a participação de Lázaro nos acontecimentos narrados é mínima. Muito já se falou sobre a pouca participação de Lázaro no quinto tratado; um exemplo disto é o que diz Ayala (1971:70):

Y esta novedad chocante que nos llama la atención en el tratado quinto del Lazarillo: llegados a su altura, el personaje que es objeto del libro, y cuyo centro ha ocupado hasta ahora, se echa a un lado y pasa a desempeñar el papel pasivo de testigo-relator: durante todo el capítulo Lazarillo mismo no tiene arte ni parte; está colocado al margen.

Mas não é por acaso que Lázaro se coloca à margem do que acontece no quinto tratado; ele se põe no lugar de espectador como todo o público que assiste à atuação do buleiro e de seu cúmplice, sentindo a mesma surpresa que sentiram as outras pessoas que estavam presentes a tal situação.

Lázaro, que nesse momento já havia aprendido muito com seus amos anteriores, que já não era tão ingênuo como quando vivenciou o episódio da "cornada", é também enganado pelo buleiro. Ao dar-se conta da situação criada por seu quinto amo, pensa:

"¡Cuántas déstas deben hacer estos burladores entre la inocente gente!" (p. 125)

O fato de Lázaro não participar da ação, não torna esse tratado menos importante para a obra. Lázaro foi enganado como todas as pessoas, mas, após 
descobrir o que realmente aconteceu, percebe o quanto pode ser interessante calar-se em alguns momentos, que o silêncio pode ter as suas vantagens.

Pensando ainda no que aprende a personagem, percebemos que Lázaro aprende algo com cada um de seus amos; aliás, esse aprendizado se reflete nos seus pensamentos. Assim, podemos ter:

- Com o cego: Lázaro aprende que depende somente de si para sobreviver.

- Com o clérigo: A personagem reconhece a hipocrisia dos representantes da Igreja, que não praticam o que dizem.

- Com o escudeiro: Aprende a lidar com as aparências, com o jogo de que ao parecer-se a algo, pode chegar a sê-lo.

- Com o buleiro: Lázaro aprende a calar-se, a não mais manifestar os seus pensamentos, além de aprender também a mentir.

Lázaro aprende tão bem as lições de seus amos, que chega a ser parecido com eles. Assim, da mesma forma como o cego vivia de suas palavras, Lázaro, como pregoeiro, também vive delas; se o clérigo vivia da Igreja, ele a seu modo, também; se o escudeiro vivia ostentando uma realidade que não era a dele (e acreditava nela), a nossa personagem também; com relação ao buleiro, este também vivia de suas palavras, ou melhor, da mentira. Ele sabia falar e calar no momento certo, além de saber enganar as pessoas para proveito próprio, algo que a personagem também aprendeu. 
Desta forma, temos em Lázaro um homem que tem consciência de que depende somente de si para sobreviver, que vive próximo à hipocrisia dos membros da Igreja, que mantém as aparências de homem de bem, e que principalmente sabe mentir e calar.

A lição do silêncio é extremamente importante para a manutenção do momento presente da personagem, e essa lição é tão bem aprendida que depois do quinto tratado, Lázaro não expressa mais nenhum pensamento.

\subsection{LÁZARO COMO NARRADOR}

O narrador em Lazarillo de Tormes talvez seja o elemento desta obra mais estudado atualmente. Lázaro é um narrador que não somente narra os acontecimentos de sua vida, como também tece comentários e juízos de valor sobre eles.

As intromissões desse narrador acontecem sempre em tempo presente, em contraste com o passado utilizado para a narração das suas lembranças, assim, além de narrar o que ocorreu no passado, sente-se à vontade para apresentar comentários acerca daquilo que narrou.

Estes enunciados, que trazem em si comentários do narrador, foram aqueles catalogados por Mario González (1994:122) como frases de tipo "c".

Os comentários de Lázaro como narrador estão presentes em todos os tratados, menos no sexto. Não consideraremos neste momento da análise o tratado VII, que se encontra todo inserido no momento da enunciação, momento presente 
do narrador. Trataremos aqui, somente da parte da narrativa em que o narrador se refere ao seu passado.

Nos comentários do narrador, são freqüentes alguns temas, os quais separamos em: referências religiosas, crítica à sociedade e referências pessoais.

Ao definir um tema como "referências religiosas", pretendemos dar ênfase à crítica que Lázaro-narrador faz aos representantes da Igreja, além de salientar sua capacidade de ironizar e de tornar ambígüas situações que, a princípio, não apresentam nenhum tipo de comicidade ou duplo sentido, mas que narradas a partir de referências religiosas, recebem uma pluralidade de significados.

Encontramos, então, enunciados que ironizam algumas situações, como por exemplo, a prisão do pai de Lázaro, que no momento em que é narrada, recebe do narrador diversas referências do tradicional discurso religioso, que, ao mesmo tempo que ironizam, têm a capacidade de amenizar a história do pai do narrador, assim temos:

\footnotetext{
Pues siendo yo niño de ocho años, achacaron a mi padre ciertas sangrías mal hechas en los costales de los que allí a moler venían, por lo cual fue preso, y confesó y no negó, y padeció persecución por justicia. Espero en Dios que está en la gloria, pues el Evangelio los llama bienaventurados. (p. 14 - grifo meu)
}

Como podemos observar, temos claras referências ao discurso religioso nesse comentário de Lázaro. O verbo confessar, muito relacionado à prática católica, ou mesmo o verbo negar, que facilmente pode ser visto como uma evocação da passagem do Evangelho onde Pedro nega conhecer Jesus Cristo, formam junto a "padeció persecusión por justicia", outra referência ao Evangelho, 
desta vez do "Sermão da montanha" (Mt.,5,10), uma subversão desse discurso religioso.

Lázaro se apropria de tal discurso e o subverte a fim de amenizar a história de seu pai. O narrador, que no momento em que narra já é adulto e aprendeu o quanto as aparências são importantes na sociedade em que vive, sabe que não pode dizer claramente que seu pai era um ladrão, assim torna sua história ambígüa. A ironia, porém, é nesse caso um pouco mais aguda, uma vez que discurso religioso é subvertido para suavizar a história de um ladrão, de um pecador.

Mas a questão religiosa nos comentários de Lázaro não termina nesse comentário. Lázaro faz sérias críticas aos representantes da Igreja em meio a seu discurso; desta forma, tratando da relação amorosa de sua mãe com o negro Zaide e da perseguição que sofrem, diz:

No nos maravillemos de un clérigo ni fraile porque el uno hurta de los pobres y el otro de casa para sus devotas y para ayuda de otro tanto, cuando a un pobre esclavo el amor le animaba a esto. (p. 19)

E mais adiante na narrativa, criticando a avareza e mesquinhez do clérigo de Maqueda, comenta:

Escapé del trueno y di con el relámpago, porque era el ciego para con este un Alejandro Magno, con ser la mesma avaricia, como he contado. No digo más, sino que toda la laceria del mundo estaba encerrada en éste: no sé si de su cosecha era o lo había anejado con el hábito de clerecía. (p.47) 
Nesses dois comentários encontramos críticas que abrangem toda a categoria clerical. No primeiro comentário, Lázaro põe em questão a honestidade dos religiosos, em outro, pergunta-se se a mesquinhez, a avareza, e outras características são qualidades naturais do indivíduo que é clérigo, ou se essas "qualidades" são adquiridas com o ofício religioso.

Em geral a honestidade e a sinceridade dos religiosos são questionadas. Assim, ao caracterizar o seu quarto amo, Lázaro segue com as críticas e a ironia:

Gran enemigo del coro y de comer en el convento, perdido por andar fuera, amicísimo de negocios seglares y visitar: tanto, que pienso que rompía él más zapatos que todo el convento. (p. 110)

A hipocrisia em que vivem os clérigos e que vem sendo denunciada desde o primeiro tratado, é novamente retomada neste comentário.

Lázaro denuncia, em meio à sua narrativa, os membros de uma instituição. Vemos que algumas vezes mais disfarçadas que outras, os comentários ácidos do narrador são como um desabafo frente à injustiça e à corrupção que fazem parte da vida desses homens.

Seguindo os temas que propusemos, chegamos às "críticas à sociedade". Neste tema, Lázaro denuncia algumas situações que vê, mas nestes comentários, o narrador ocupa, em geral, o papel de observador, como se não fizesse parte desta sociedade.

O narrador observa situações cotidianas do meio social em que vive, assim, diz: 
(...) dos rebozadas mujeres, al parecer de las que en aquel lugar no hacen falta (p. 85)

Lázaro fala da falta de solidariedade das pessoas, fala da quantidade de moças que se prostituem, mas é, como dissemos, como se ele não fizesse parte dessa realidade. Ele se distancia de uma realidade e no papel de observador, comenta o que vê. Em um momento, porém, o narrador se compromete, e este comentário tem muito a dizer:

Dios es testigo que hoy día, cuando topo con alguno de su hábito con aquel paso y pompa, le he lástima con pensar si padece lo que aquél le vi sufrir. Al cual, con toda su pobreza holgaría de servir más que a los otros, por lo que he dicho. Sólo tenía dél un poco de descontento, que quisiera yo que no tuviera tanta presumpción, mas que abajara un poco su fantasía con lo mucho que subía su necesidad. Mas, según me parece, es regla ya entre ellos usada y guardada. Aunque no haya cornado de trueco, ha de andar el birrete en su lugar. El Señor lo remedie, que ya con este mal han de morir. (p.92)

Lázaro critica a postura do escudeiro, que vivia uma "fantasia", que vivia de uma aparência que na verdade não era real. Temos uma crítica a toda uma classe social, a dos fidalgos, que conservavam o "birrete en su lugar", mesmo que não tivessem meios para sobreviver. Há aqui uma crítica a uma sociedade de aparências, onde parecer é mais importante que ser, onde a imagem projeta a realidade.

Não podemos nos esquecer, porém, de que Lázaro é fruto dessa sociedade, e que vive essa mesma realidade de aparências; o "caso", como veremos adiante é um exemplo disso. 
No tema intitulado "referências pessoais", Lázaro comenta algumas situações que viveu, e nos dá indicações a respeito do que pensa como homem adulto no momento em que escreve, como vê a realidade.

Encontramos, então, enunciados como estes:

Y fue ansí, que, después de Dios, éste me dio la vida y, siendo ciego, me alumbró y adestró en la carrera de vivir. (p. 24)

Lázaro como "mozo de ciego", começa a aprender, com seu primeiro amo, a reagir diante das diversidades. É o cego quem lhe ensina que está só no mundo, é quem Ihe desperta da simplicidade da infância.

A ironia, neste caso, é simples, quem the ilumina para a vida é um homem que não pode ver a luz. Podemos pensar no tipo de aprendizado que Lázaro obteve com esse mestre, que da escuridão em que vivia the mostra como sobreviver.

Tratando ainda do tema "referências pessoais", podemos observar o seguinte comentário do narrador:

Y pienso, para hallar estos negros remedios, que me era luz la hambre, pues dicen que el ingenio con ella se avisa, y al contrario con la hartura, y así era por cierto en mí (p. 62)

Nesse comentário, Lázaro evidencia mais um elemento que contribui para a sua formação: a fome. 
A fome, motivadora das maiores peripécias de Lázaro, como ele mesmo diz, incentiva o desenvolvimento do engenho; para não sofrer a dor da fome, Lázaro é obrigado a pensar e a reagir frente ao que the é imposto.

Há outro comentário do narrador que também reflete o olhar da personagem sobre si mesma e que não deixa de caracterizá-la:

Cuando él hizo el ensayo, confieso mi pecado, que también fui dello espantado y creí que ansí era, como otros muchos; mas con ver después la risa y burla que mi amo y el aguacil llevaban y hacían del negocio, conoscí cómo había sido industriado por el industrioso e inventivo de mi amo. (p. 123)

Esse comentário, expresso após a descoberta do golpe do buleiro, nos chama a atenção pela expressão "confieso mi pecado". Ao utilizar o termo "pecado", Lázaro pode ter se referido ao fato de estar desatento à situação. Após tudo o que já havia aprendido com seus amos anteriores, principalmente com o escudeiro, Lázaro sabe que não pode se deixar levar pelas aparências, mesmo as mais reais, como a criada pelo seu quinto amo.

As experiências de vida fizeram de Lázaro um homem preparado para o mundo. A partir de seus comentários, encontramos um homem capaz de perceber como funciona a sociedade em que vive, capaz de criticar e satirizar situações que povoam o seu cotidiano. Estamos diante de um homem maduro que critica a sociedade da qual é fruto, mas que paradoxalmente, não se reconhece nela. 


\title{
3. O "CASO"
}

O "caso" que vivencia Lázaro é o elemento motivador de toda a sua narrativa. Mais que motivador, o "caso" que Lázaro pretende contar a Vuestra Merced é, na verdade, o eixo em torno do qual gira todo o discurso do narrador.

\section{Lázaro começa sua carta dizendo que explicará a Vuestra Merced o} "caso", e é com ele que termina a narrativa. Este "caso" abre e fecha o Lazarillo, com a sua exposição, a proposta do narrador se realiza e a obra se completa. É o que diz Francisco Rico (1989:24):

\begin{abstract}
El caso es, pues, el pretexto de La vida de Lazarillo de Tormes. Pero no sólo eso: es, también, el asunto último de la novela. Importa no perder de vista la capital advertencia del Prólogo: si tenemos "entera noticia" del protagonista, agradezcámoslo a que Lázaro ha decidido no tomar "el caso... por el medio, sino del principio". La autobiografía, así, depende del caso y a la vez lo justifica; o (para aplicar los términos familiares de Ferdinan de Saussure) se nos presenta entendida como la dimensión "diacrónica" del caso, como su trayectoria a lo largo de un "eje de sucesiones" de entre los varios que componen la entera existencia de Lázaro. Lázaro, el individuo, asume el pasado en función de su presente de pregonero satisfecho con las "mil mercedes" que Dios le envía a través de su mujer y el Arcipreste; y el Lazarillo, la carta, se organiza en la convergencia de los diversos episodios anteriores hacia el caso del capítulo final.
\end{abstract}

A exposição do "caso" é também crucial para a construção do sentido da obra. A partir da sua leitura, o leitor é obrigado a tomar uma posição frente às palavras do narrador, que neste momento, já não se reporta ao seu passado, ele trata o que acontece em seu presente.

Antes de expor o caso, Lázaro descreve toda a sua vida. Não esconde do leitor as suas peripécias ou trapaças, o seu crescimento e desenvolvimento são elementos que o caracterizam como personagem. 
Vimos que ao longo da narrativa poderíamos encontrar alguns pensamentos críticos de Lázaro quando era personagem da narrativa que construía como narrador, além de alguns comentários desse mesmo narrador em relação ao que narrava. Vimos também que esses pensamentos ou comentários se extinguiam na medida em que a narrativa se aproximava do momento em que Lázaro narrava.

Os comentários críticos que apresenta Lázaro estão relacionados ao passado, eles já não atingem o seu presente, e se pensarmos que Lázaro, além de explicar o caso, diz em sua carta pretender expor a sua capacidade de "crescer" socialmente, tais críticas em meio ao seu relato funcionam como exemplos das dificuldades que teve de vencer. As críticas acabam exaltando a personagem e a façanha de crescer socialmente em uma sociedade onde não havia mobilidade social.

O desaparecimento dos comentários críticos de Lázaro, conforme esse se aproximava do momento da enunciação, tem um motivo claro: a personagem neste momento já estava completamente integrada à sociedade que antes criticava, Lázaro assumiu para si aquilo que antes reprovava e, sendo parte dessa sociedade, já não era capaz de criticar a situação que vivia.

O Lázaro que escreve a Vuestra Merced é resultado de suas experiências, sabemos que ele aprendeu muito com os seus amos anteriores, aprendeu como funciona a sociedade em que vive e os seus valores, além, é claro, do fato de nesta sociedade a aparência ser extremamente importante. Ele aprendeu que parecer ser algo é o mesmo que sê-lo, assim, ao comprar roupas usadas e vestir-se como um homem de bem, Lázaro sabia que com essa aparência, seria reconhecido pelo que aparentava ser e não pelo que era realmente. 
Esse é o Lázaro que protagoniza o "caso". Um homem completamente integrado a um sistema social baseado nas aparências; ele parece ser um homem de bem, e isso faz com que se veja assim (algo parecido com o que viveu ao lado do escudeiro).

Vejamos qual é o "caso": Lázaro conta a Vuestra Merced que é alvo das más línguas que afirmam que sua mulher é adúltera, sendo amante do Arcipreste de San Salvador. Tal pessoa era amo de Lázaro Ihe havia arranjado o casamento.

Nesse momento de sua vida, Lázaro já não padece como antes, a fome não o persegue mais e ele vive de um oficio real, é um pregoeiro. Nas horas vagas, a personagem também presta serviços ao Arcipreste, pregoando os seus vinhos.

A relação de Lázaro com o Arcipreste aos poucos vai se esclarecendo. Percebemos que com o seu novo amo e com o seu casamento, Lázaro havia alcançado, enfim, uma vida confortável:

Y, así, me casé con ella, y hasta agora no estoy arrepentido, porque, allende de ser buena hija y diligente servicial, tengo en mi señor acipreste todo favor y ayuda. Y siempre en el año le da, en veces, al pie de una carga de trigo; por las Pascuas, su carne; y cuando el par de los bodigos, las calzas viejas que deja. E hízonos alquilar una casilla par de la suya; los domingos y fiestas, casi todas comíamos en su casa. (p. 131)

O Arcipreste tem com Lázaro mais que uma relação de senhor e servo, Lázaro além de receber favores seus, é também o seu protegido. A personagem goza a sua prosperidade, porém, esta vida próspera estava sendo ameaçada pelos comentários que existiam sobre a sua esposa e a relação que mantinha com o Arcipreste. 
Os comentários sobre o adultério da esposa afetam mais que o amor próprio da personagem, afetam a sua honra. Lázaro tem uma imagem a zelar e o adultério da esposa manchava a imagem de homem de bem que ele ostentava, além de manchar também a imagem do seu novo amo.

Frente às acusações que recebia, Lázaro se recusa a admitir o amancebamento de sua esposa com o Arcipreste. Ele se recusa a aceitar o que se apresenta em sua vida e leva em consideração que lhe diz o Arcipreste em uma conversa:

\footnotetext{
- Lázaro de Tormes, quien ha de mirar a dichos de malas lenguas nunca medrará; digo esto porque no me maravillaría alguno viendo entrar en mi casa a tu mujer y salir della. Ella entra muy a tu honra y suya. $Y$ esto te prometo. Por tanto, no mires a lo que pueden decir, sino a lo que te toca: digo a tu provecho.

- Señor - le dije -, yo determiné de arrimarme a los buenos. Verdad es que algunos de mis amigos me han dicho algo deso, y aun por más de tres veces me han certificado que antes que comigo casase había parido tres veces, hablando con reverencia de Vuestra Merced, porque está ella delante. (p. 132)
}

O comentário do Arcipreste expressa o que ele espera de Lázaro: o pregoeiro deve cuidar de sua vida, e ignorar o que dizem as "más línguas" sobre sua mulher, deve pensar em si, no que é de seu proveito.

A expressão "arrimarse a los buenos", que já foi utilizada na narrativa antes para descrever a situação em que vivia a mãe de Lázaro, é utilizada pelo pregoeiro de forma irônica para tratar da situação que vive. Nesse momento, tal expressão pode assumir dois sentidos: o de tirar proveito de pessoas "bem sucedidas", ou mesmo o de aproximar-se de pessoas de "boa índole". 
É irônico que Lázaro diga que determinou "arrimarse a los buenos", quando tem uma vida favorecida pelo contato que tem com o Arcipreste, justamente a pessoa que é acusada de manter um caso amoroso com sua esposa.

Lázaro, que já havia aprendido com a sua mãe o significado de "arrimarse a los buenos", e também somado um grande aprendizado com os seus amos anteriores, pôde determinar o que seria melhor para ele.

"Arrimarse a lo buenos" é o que faz então: está ao lado do Arcipreste, uma pessoa poderosa. Ele desfruta dos benefícios que obtém pela proximidade com o religioso, mas isso tem um preço alto para a personagem, já que esses benefícios não existem por acaso, é a relação do Arcipreste com a esposa de Lázaro a responsável pelos favores que recebe.

O Arcipreste é mais um exemplo da importância da aparência para essa sociedade. Por trás da imagem de religioso, que lhe garante o reconhecimento de todos, ele mantém uma relação adúltera com a esposa de Lázaro.

Lázaro encontra-se em uma situação difícil, já que aceitar os comentários sobre o adultério de sua esposa, além de ferir a sua honra pode pôr em risco a situação confortável em que vive. O pregoeiro deve escolher entre defender a sua honra ou manter o estilo de vida que tem, ignorando e mesmo negando os comentários que chegam a ele.

Em nenhum momento Lázaro acusa a sua esposa ou o Arcipreste de adultério. O pregoeiro prefere não se comprometer com o seu novo senhor e também não correr o risco de ter a sua honra manchada. Lázaro defende a sua esposa das acusações de que é alvo: 
Hasta el día de hoy nunca nadie nos oyó sobre el caso; antes cuando alguno siento que quiere decir algo Della, le atajo y le digo:

-Mirá, si sois mi amigo, no me digáis cosa con que me pese, que no tengo por mi amigo al que me hace pesar. Mayormente, si me quieren meter mal con mi mujer, que es la cosa del mundo que yo más quiero y la amo más que a mí, y me hace Dios con ella mil mercedes y más bien que yo merezco. Que yo juraré sobre la hostia consagrada que es tan buena mujer como vive dentro de las puertas de Toledo. Quien otra cosa me dijere, yo me mataré con él.

Desta manera no me dicen nada, y yo tengo paz en mi casa. (p. 134)

Vemos que Lázaro, não só defende a sua esposa, como defende principalmente a si mesmo, pois, como ele mesmo diz: quem é seu amigo não deve dizer coisas que possam causar-Ihe algum pesar.

A fala de Lázaro é ambígua, o pesar que deseja evitar, tanto pode estar relacionado ao sofrimento de ser traído, como também pode relacionar-se ao fato dele preferir que não criem situações prejudiciais ao seu estado atual, pois se tocassem no assunto do adultério de sua esposa, ele teria de assumir uma posição em defesa de sua honra, colocando em risco a situação cômoda em que vivia.

A lição que teve Lázaro com o buleiro, a de calar-se, novamente é retomada aqui: Lázaro não somente sabe calar-se, mas espera que aqueles que o cercam também o façam. O pregoeiro prefere que o silêncio se instale, já que se o assunto do adultério não for tocado, é como se não existisse. Com isso, a personagem não se compromete, não tem a obrigação de defender a sua honra e muito menos de afrontar o Arcipreste.

Deus, que anteriormente apareceu com freqüência nos pensamentos de Lázaro é evocado agora pela personagem da mesma forma que antes: como um "cúmplice". Nesse momento ele diz que "me hace Dios con ella mil mercedes y más bien que yo merezco", ou seja, Deus Ihe faz um favor colocando sua esposa em sua vida. 
Mais uma vez temos um comentário irônico: as "mil mercedes" que Lázaro recebe com sua esposa poderiam estar relacionadas à sua vida de casado, ao amor que sentiria por sua mulher, ou poderiam também relacionar-se aos favorecimentos que obtém o narrador a partir de sua relação com esta pessoa.

Temos em toda a narrativa do "caso" comentários irônicos ou ambíguos do narrador, e é somente depois de tomar uma posição frente à narrativa da personagem, depois de conhecer a sua história, que o leitor pode construir a sua leitura da obra. Ele deve escolher um ponto de vista para encarar o discurso de Lázaro.

Reconhecendo toda a trajetória da personagem, que durante sua infância demonstra ser extremamente crítica em relação à sua realidade, mas que conforme se aproxima do que é como adulto abandona esse olhar crítico e se integra à sociedade que antes era o alvo de sua crítica, o leitor pode reconhecer que Lázaro pouco a pouco foi se corrompendo. Vejamos o que diz Rodríguez Puértolas (1981:266):

\footnotetext{
Mas la historia de Lázaro es la historia de una corrupción, y esos apartes, que ocurren de forma abundante en los tres primeros capítulos, van desapareciendo progresivamente conforme el nuevo tipo de héroe avanza en su descomposición humana, es decir, en su aceptación - que será absoluta - del esquema de 'valores' de su sociedad, en su integración en el sistema. La desaparición de los apartes, de los comentarios independientes de Lázaro ante una realidad y un mundo con los cuales disiente, coincide con la brevedad y esquematismo de los capítulos IV, VI y comienzo del VII, en que la narración queda reducida al mínimo. Sin duda que tras estos brevísimos episodios y tras el marginamiento de Lázaro en el capítulo V - la historia de un vendedor de bulas - algo ha estado sucediendo; la relación dialéctica de entre Lázaro y el mundo ha continuado, pero el joven héroe, que era capaz de reaccionar ante la maldad o la estupidez por medio de sus observaciones íntimas, ha perdido ya tal aptitud. Este es exactamente el punto en que la novela y protagonista cambian de dirección: Lázaro ha terminado por comprender demasiado bien un mundo que al comienzo no entendía. El capítulo $\mathrm{VI}$, con ser tan corto, es el más significativo, pues es aquel en el que Lázaro manifiesta sin ambages su deseo, nunca confesado antes de ahora, de integrarse en el sistema de mitos de la época, comenzando por lo más
} 
exterior: jubón, sayo, capa y espada, 'para me vestir muy honradamente de la ropa vieja'. Lázaro ha sido asimilado y precisamente en el violento contraste de esa asimilación - es decir, corrupción - del personaje y del punto de vista del autor radica la verdadera talla de éste. Aquí es donde se funden los dos planos de la novela llamada Lazarillo de Tormes, el del héroe y el del autor. Corrupción e integración son totales, así como la destrucción del yo. Corrupción en la cual participan en mayor o menor grado todos los personajes del libro, incluido el Vuestra Merced del prólogo y del capítulo final, a quién Lázaro dice enviar la obra.

Podemos ver a Lázaro como uma personagem que se integrou tão completamente à sociedade que antes criticava a ponto de perder o olhar crítico de antes. Lázaro vestiu-se como um homem de bem, e acreditou que o era. Tal qual o escudeiro, a personagem é incapaz de perceber a situação na qual está imersa. Ele é cego frente ao adultério de sua esposa e não vê que é usado pelo Arcipreste.

Esse Lázaro, mais cego que o seu primeiro amo, internalizou o sistema social em que vivia. Ele não poderia mais criticar esse meio, porque agora fazia parte dele. Antes ele era um marginal que olhava de fora um sistema corrompido e o denunciava. Ao fazer parte desse sistema, Lázaro é tão corrompido quanto ele, e, portanto, incapaz de criticá-lo.

Porém, é interessante que na exposição do caso feita por essa personagem alienada e cega frente à sua realidade, percebamos tanta ironia e ambigüidade. Lázaro não é capaz de ver a situação na qual está imerso, mas mesmo assim tem um discurso que pode ter diferentes interpretações.

Frente ao discurso de Lázaro que, apesar de negar o adultério da esposa, expõe o caso de forma ambígua e irônica, o leitor é levado a compreender que provavelmente o adultério de que são acusados o Arcipreste e a esposa de Lázaro seja real. 
O leitor pode optar por considerar, a partir da história de Lázaro, que o protagonista realmente decidiu "arrimarse a los buenos", que ele decidiu apoiar-se naqueles que poderiam tornar a sua vida melhor.

Este Lázaro também seria corrompido pelo meio em que vivia e assumiria uma vida conforme os valores da sociedade que tanto criticou. Essa personagem aprendeu o que deveria fazer para sobreviver em um mundo de aparências.

A personagem, depois de tanto esforço para alcançar uma vida melhor da que tinha antes, aceitaria a situação de adultério imposta pelo Arcipreste em troca de uma vida confortável.

Em qualquer uma dessas possibilidades de leitura, Lázaro foi corrompido pelo meio em que estava imerso. O olhar crítico que possuía se perdia conforme a personagem assimilava os valores da sociedade que o excluía, e na medida em que Lázaro era incluído socialmente, sua capacidade crítica desaparecia. 


\section{CAPÍTULO 5}

\section{A VOZ DO AUTOR IMPLÍCITO NA}

\section{NARRATIVA DE LÁZARO DE TORMES}

Quando estudamos o prólogo do Lazarillo, tivemos o nosso primeiro contato com o autor implícito da obra. No prólogo, o autor implícito pôde colocar-se abertamente, já que esse é o espaço destinado para que a voz desse autor se coloque.

No prólogo, observamos a forma como esse autor implícito se impunha, como apresentava a obra, além, é claro, de sua posição frente a ela e frente ao público leitor.

Ao longo da narrativa, porém, o autor implícito de Lazarillo de Tormes não pôde se colocar explicitamente. Sabemos que ele é o responsável pela obra, por sua organização, enfim, pelo todo que chega às mãos do leitor, mas a voz que se mostra dentro da narrativa apresentando-a, não é a dele, é a voz do narrador.

O autor implícito é o responsável pelo narrador, é ele quem lhe dá vida, e em suas mãos o narrador é como uma marionete que reproduz o que lhe é imposto.

Sendo o responsável pelo narrador da obra, e por toda ela, o autor implícito tem também a responsabilidade de manter a ilusão que se cria dentro da narrativa. Dessa maneira, o narrador criado por ele deve apresentar o seu discurso com propriedade para que esse discurso seja acatado pelo leitor. Esse é o motivo 
pelo qual é comum que a voz do autor implícito seja quase imperceptível dentro de uma narrativa.

O fato de ser difícil reconhecer a voz do autor implícito dentro de uma obra, não significa que ela não exista. Camuflado nas falas das personagens ou no discurso do narrador, o autor implícito não deixa de existir e não deixa de expor o seu ponto de vista, que pode, por vezes, não coincidir com o ponto de vista do narrador.

No caso do Lazarillo de Tormes, não seria diferente. Ao longo da narrativa de Lázaro, podemos perceber alguns comentários - tanto de Lázaro como personagem, como de Lázaro como narrador - que parecem representar opiniões não necessariamente condizentes com a sua posição.

Tais comentários, que acreditamos representar o ponto de vista do autor implícito, geram o que consideramos ser contradições no discurso de Lázaro, uma vez que esses muitas vezes se mostram como opostos às práticas ou posicionamentos da personagem.

Esses comentários na maioria das vezes transformam Lázaro em uma personagem que tem um discurso diferente do que faz, transformam-no em uma personagem contraditória. É por meio dessas contradições que percebemos que pouco a pouco vai se estabelecendo o sentido da obra, como veremos no próximo capítulo.

O primeiro exemplo de comentário que acreditamos representar o ponto de vista do autor implícito aparece no início da narrativa de Lázaro. Expresso como um pensamento da personagem, quando essa ainda era uma criança, temos: 
"iCuántos debe de haber en el mundo que huyen de otros porque no se veen a sí mesmos!" (p. 18)

Esse comentário, que já havíamos visto antes, quando tratávamos dos pensamentos de Lázaro como narrador, parece-nos contraditório se procurarmos associá-lo ao momento em que aparece na narrativa.

A personagem ainda vivia a infância quando tal pensamento foi expresso e parece-nos que a complexidade desse pensamento não condiz com a sua situação infantil. Um pensamento como o expresso pela personagem extrapola a sua capacidade naquele momento.

Tal comentário critica uma sociedade que cultua as aparências e volta o seu olhar para o próximo classificando-o pela imagem que apresenta. É uma critica à cegueira daqueles que se preocupam em enxergar a imagem de alguém, sem reconhecer a si mesmos.

Esse comentário, que vai além do discurso de Lázaro, mostra-se como uma contradição não só em relação ao momento em que é expresso pela personagem, sua infância, como também em relação a sua posição final, se pensarmos que Lázaro se integrou completamente à sociedade criticada, já não conseguindo enxergar a sua própria imagem.

Mas essa não é a única contradição no discurso de Lázaro, encontramos mais adiante na narrativa o comentário adiante, que desta vez não aparece como um pensamento da personagem, mas como parte do discurso do narrador: 
Tratando do relacionamento de sua mãe com Zaide e da perseguição que sofreram, Lázaro expressa o comentário acima, e aproveitando-se da situação, o autor implícito utiliza a relação de Zaide com a mãe de Lázaro, para criticar a hipocrisia em que viviam aqueles religiosos que mantinham relações amorosas (ou mesmo famílias) apesar do conhecido voto de celibato da Igreja.

Temos então mais uma contradição no discurso de Lázaro, pois como sabemos, sua esposa mantém uma relação extraconjugal com um membro da Igreja, o Arcipreste de Sant Salvador, e o comentário acima não deixa de ser uma referência a essa relação. Por outro lado, sabemos também que Lázaro se recusa a crer nas acusações de adultério feitas à sua esposa.

Tal é a contradição que temos aqui: Lázaro defende sua esposa e o Arcipreste das acusações de adultério, porém apresenta um comentário criticando os religiosos que mantêm relações amorosas.

A crítica apresentada nesse momento delata a hipocrisia dos religiosos que pregavam a fidelidade e juravam o celibato, mas que não praticavam o seu discurso.

Temos também a crítica a uma sociedade que perseguia e julgava aqueles que eram diferentes, julgava os pobres e fechava os olhos para os abusos que poderiam ser cometidos por quem fizesse parte de um grupo social de prestígio.

Os clérigos eram vistos como verdadeiros homens de bem, como grandes exemplos a serem seguidos, além é claro de serem os representantes da Igreja, instituição de grande poder e prestígio na época. O fato de serem vistos 
como homens de bem, protegia-os de prováveis julgamentos. A imagem que projetavam se tornava a verdade sobre eles.

O olhar crítico do autor implícito se deitou novamente sobre a questão da importância das aparências para a sociedade espanhola da época, mas dessa vez a sua crítica dá maior ênfase aos representantes da lgreja.

Tratando ainda dos representantes da Igreja, encontramos outro comentário que forma uma contradição no discurso de Lázaro. Este comentário aparece novamente no discurso do narrador:

No digo más, sino que toda la laceria del mundo estaba encerrada en éste: no sé si de su cosecha era o lo había anejado con el hábito de clerecía. (p.47)

Nesse comentário que aparece quando Lázaro trata de seu segundo amo, o clérigo de Maqueda, percebemos mais uma crítica que se dirige diretamente aos representantes da Igreja.

O comentário questiona se a mesquinhez do clérigo de Maqueda era algo inerente a ele ou se essa mesquinhez havia sido adquirida pelo "hábito religioso", pelo aprendizado que obtido na instituição a que servia, a Igreja.

Não há como ignorar a crítica presente nesse comentário. É abertamente questionada a avareza e a mesquinhez praticadas por alguns representantes da Igreja, justamente aqueles que deveriam ser exemplo de desprendimento e bondade, segundo a filosofia católica.

Com essa crítica vemos que não só as pessoas comuns dessa sociedade se corromperam, mas também dos representantes da lgreja também foram 
corrompidos. O comentário denuncia que a instituição que deveria zelar pelos valores morais da sociedade tinha representantes corrompidos por ela mesma e que, esses representantes eram hipócritas ao pregarem uma mensagem e agirem de forma diferente do que diziam.

O importante neste caso é, novamente, a imagem que ostentam. Os representantes da Igreja são homens de bem exatamente pela instituição que representam, não pelo que são.

A contradição existente nesse comentário de Lázaro diz respeito ao fato de Lázaro viver dos favores de um desses membros da Igreja. Criticar os membros dessa instituição seria o mesmo que incluir nessa crítica o seu novo amo.

Lázaro decidiu "arrimarse a los buenos", e mantinha assim a sua relação de favores com ao Arcipreste. Criticar o grupo a que pertencia o religioso, significaria criticá-lo e acusá-lo também, algo que poderia prejudicar a situação vivida pela personagem.

A imagem é tema de mais comentários que podem apresentar o ponto de vista do autor implícito. Veremos abaixo dois comentários de Lázaro, ambos tratando do escudeiro:

\footnotetext{
"Bendito seáis Vós, Señor - quedé yo diciendo - , que dais la enfermedad y ponéis el remedio. ¿Quién encontrará a aquel mi señor que no piense, según él contento de sí lleva, haber anoche bien cenado y dormido en buena cama, y, aun agora es de mañana, no le cuenten por muy bien almorzado? ¡Grandes secretos son, Señor, los que Vós hacéis y las gentes ignoran! ¿A quién no engañará aquella buena disposición y razonable capa y sayo? ¿Y quién pensará que aquél gentil hombre se pasó ayer todo el día sin comer, con aquel mendrugo de pan que su criado Lázaro trujo un día y una noche en el arca de su seno, do no se le podía pegar mucha limpieza, y hoy, lavándose las manos y cara, a falta de paño de manos se hacía servir de la halda del sayo? Nadie, por cierto, lo sospechará. ¡Oh, Señor, y cuántos de aquestos debéis Vós tener por el mundo derramados, que padescen por la negra que llaman honra lo que por Vós no sufrirán!” (p. 83 - grifo meu)
} 
Dios es testigo que hoy día, cuando topo con alguno de su hábito con aquel paso y pompa, le he lástima con pensar si padece lo que aquél le vi sufrir. Al cual, con toda su pobreza holgaría de servir más que a los otros, por lo que he dicho. Sólo tenía dél un poco de descontento, que quisiera yo que no tuviera tanta presumpción, mas que abajara un poco su fantasía con lo mucho que subía su necesidad. Mas, según me parece, es regla ya entre ellos usada y guardada. Aunque no haya cornado de trueco, ha de andar el birrete en su lugar. El Señor lo remedie, que ya con este mal han de morir. (p.92 - grifo meu)

Tanto o primeiro comentário, que aparece como um pensamento de Lázaro, quanto o segundo, que aparece no discurso do narrador, tratam da mesma questão: a imagem que pode ostentar alguém.

Ao comentar a forma como o escudeiro se colocava e a imagem que ostentava, Lázaro critica novamente a importância da imagem para a sociedade em que estava inserido. O escudeiro era um miserável que não conseguia ao menos alimentar-se, porém ostentava uma imagem próspera.

Mais que ostentar somente a imagem de um fidalgo, de um homem próspero, o escudeiro acreditava sê-lo. Ele era incapaz de reconhecer o estado de total miséria em que se encontrava.

A crítica que encontramos demonstra a alienação em que estava submersa toda uma sociedade. A aparência havia se tornado tão importante que o simples fato de aparentar algo fazia com que se acreditasse sê-lo. Já não existia nesta sociedade a capacidade de olhar criticamente para a forma como viviam todos.

Temos nesses comentários uma das maiores contradições de Lázaro. Ele é capaz de perceber o que acontece com o escudeiro, de sentir pena desse homem que vive de sua imagem, mas é incapaz de perceber que o mesmo ocorre com ele. 
Lázaro, no momento em que narra o caso, em seu presente, acredita ser um homem de bem, acredita ser honrado, mas é incapaz de perceber o quão desonrada é a situação que vive com a esposa e o Arcipreste.

A personagem é tão alienada quanto o escudeiro, e mais, é incapaz de percebê-lo. Ela não consegue reconhecer que tem a mesma atitude de seu antigo amo e que é como uma caricatura daquele que lhe causa pena.

Pensando nessa situação da personagem, que fica clara no final da narrativa, podemos repensar o tratado final que explica o caso motivador da obra.

No último tratado, momento em que Lázaro narrador e personagem coincidem, percebemos que não há mais no discurso do narrador qualquer comentário contraditório. Eles desaparecem da narrativa assim como os pensamentos expressos por Lázaro como personagem ou os comentários de Lázaro como narrador.

Porém, se olharmos com atenção para esta parte da obra, perceberemos que ela está povoada de ambigüidades e ironia. Já não temos contradições, mas temos uma multiplicidade de sentidos que podem apontar para o ponto de vista do autor implícito.

Como vimos no capítulo anterior, Lázaro em nenhum momento de sua narrativa acusa a sua esposa ou o Arcipreste de adultério. Ao contrário, prefere aceitar a defesa de sua esposa e os conselhos de seu amo frente aos comentários das más línguas, porém, ainda que assuma essa posição, o seu discurso, a partir da ironia e ambigüidades, aponta também para a denúncia do adultério.

É como se houvesse na descrição do caso dois pontos de vista justapostos: um em defesa do Arcipreste e da esposa de Lázaro, e outro 
denunciando o adultério. No primeiro caso encontraríamos o olhar de Lázaro e no outro, o do autor implícito.

Essa justaposição de pontos de vista acaba por denunciar ao leitor a situação em que se encontra Lázaro ao final da narrativa. A personagem diz encontrar-se em prosperidade, porém, as ambigüidades e a ironia de seu discurso apontam para uma situação desonrosa.

Este Lázaro já não é o mesmo Lázaro presente no início de suas memórias. Ele já não é crítico como antes, não tem mais a capacidade de olhar o mundo como o fazia. Talvez essa seja a maior contradição da obra, o narrador, que, completamente adaptado a esse mundo de aparências e alienado quanto à vida que leva, é o mesmo que narra o seu passado e que apresenta ao leitor o olhar crítico que tinha antes.

É contraditório que o Lázaro alienado seja capaz de apresentar todos os comentários críticos que temos na obra e que não seja capaz de reconhecer a sua realidade presente.

É claro, porém, que os comentários críticos apresentados antes pela personagem (sem contar os que apresentam contradições), em geral, estão focados em uma situação do passado em que dificilmente poderia atingir a vida cômoda que tinha no presente. Lázaro critica pontualmente os amos que teve e as situações que viveu. Os seus comentários valorizam a sua trajetória até o seu presente, já que as dificuldades que viveu demonstram o seu valor para alcançar o que considera ser a prosperidade. 
Esses comentários críticos não têm o mesmo alcance presente naqueles comentários que formam contradições na obra, aqueles que representariam o ponto de vista do narrador.

As contradições de Lázaro são causadas pela voz do autor implícito que não se cala ao longo da narrativa. Ele se mostra aos poucos, expressa o seu ponto de vista diluído no discurso do narrador, mas não deixa de se expressar.

Por meio das contradições que se formam ao longo da narrativa de Lázaro, é possível perceber um conflito entre distintos pontos de vista e diferentes interesses, o que pode contribuir para a construção do sentido da obra. 


\section{CAPÍTULO 6}

\section{A CONSTRUÇÃO DO SENTIDO NO}

\section{LAZARILLO DE TORMES}

Até agora, observamos como foi construído o Lazarillo de Tormes desde o prólogo até o final da narrativa de Lázaro. Vimos como o autor implícito apresenta a obra, como o discurso de Lázaro se forma e, finalmente, como o ponto de vista do autor implícito se integra ao discurso do narrador.

Percebemos que toda a obra, do prólogo ao discurso de Lázaro, mostrase povoada de contradições, ambigüidades e ironia. Faz-se necessário então, para interpretar o Lazarillo, compreender como esses elementos se relacionam dentro da obra e principalmente como se relacionam com o discurso do narrador.

Vimos que as contradições presentes na obra, principalmente aquelas presentes no discurso do narrador são formadas por um conflito entre diferentes pontos de vista, um que percebemos ser o do próprio narrador, Lázaro de Tormes, e outro que consideramos ser o do autor implícito.

O olhar de Lázaro em sua narrativa está focado em provar o seu valor por ter alcançado "con fuerza y maña", sem apoio algum, a prosperidade. O olhar do autor implícito, por outro lado, se dirige à questão da aparência e alienação que regem a vida de toda uma sociedade. Enquanto Lázaro está envolvido com o relato de sua vida e com a defesa de seu valor, o autor implícito denuncia o processo de corrupção da personagem, que chega ao fim de seu relato já não sendo quem era 
no início da narrativa: ele havia se tornado aquilo que antes criticava e não tem ao menos a capacidade de percebê-lo.

É na fusão desses pontos de vista opostos - o do narrador e o do autor implícito - responsáveis pelas contradições do discurso de Lázaro, que acreditamos estar a chave de leitura para o Lazarillo.

Antes de tratarmos da narrativa de Lázaro, pensemos no prólogo da obra, que é de extrema importância para a sua leitura. Nele temos o nosso primeiro contato com o autor implícito, além do fato de apresentar as primeiras contradições do romance.

A forma fantástica como o autor implícito apresenta a obra já é uma contradição. Ao apresentá-la como algo totalmente novo, com elementos "nunca oídos ni vistos", em uma clara evocação às novelas de cavalaria, vemos que contrariando o que esperaria um leitor após tal evocação, o Lazarillo nada tem de fantástico em sua temática, além disso, percebemos que a novidade exaltada no prólogo está exatamente nesse aspecto.

Apresentando uma obra escrita em "grosero estilo", ou seja, uma obra que não continha os elementos de fantasia que povoavam obras comuns à época, o autor implícito demonstra ter consciência da inovação presente no Lazarillo: escrito como um discurso que se prende ao cotidiano, à vida comum, essa obra apresenta um forte tom realista.

Eliminando a possibilidade de existência de elementos fantásticos na obra, o prólogo prepara o leitor para o que encontrará na narrativa de Lázaro: a história de vida de um homem comum, de origem pobre e que consegue, segundo ele mesmo, chegar à prosperidade. 
Mas o leitor ainda não está preparado para o discurso contraditório de Lázaro que se mostra como uma personagem que determinou para si um estilo de vida, mas às vezes expressa comentários contraditórios às suas atitudes ou mesmo às suas palavras.

Lázaro diz pretender apresentar a história de sua vida e explicar um "caso" em que estava envolvido a Vuestra Merced. Mas estando totalmente comprometido com a sua narrativa, mais do que simplesmente narrar as suas experiências, por vezes, como narrador, toma a liberdade de expressar o seu ponto de vista sobre o que vivenciou.

Lázaro emite comentários críticos sobre aquilo que narra. Seus comentários atingem desde a hipocrisia em que viviam alguns religiosos, até a alienação de uma sociedade que tinha a aparência como valor maior, onde aparentar algo seria o mesmo que sê-lo.

Lázaro também, ao narrar o seu passado, dá voz àqueles pensamentos críticos que tinha quando era mais jovem. Assim, encontramos, ao longo da narrativa, além dos comentários críticos dele como narrador, os seus pensamentos como personagem da narrativa que desenvolve.

Esses comentários críticos elaborados por Lázaro, tanto como narrador quanto como personagem, restringem-se, porém, às situações do passado da personagem. Em nenhum momento, Lázaro critica a situação em que se encontra em seu presente ou as pessoas que o cercam nessa fase de sua vida.

É como se tais comentários, relacionados a acontecimentos passados não atingissem a personagem no presente. Para Lázaro, contar as suas experiências do passado, ou mesmo criticar aqueles com quem conviveu ou serviu, 
além de demonstrar o seu valor, como um homem que venceu grandes adversidades, não pode prejudicar o seu presente. Suas críticas são restritas a pessoas que conheceu e situações terminadas, seu presente está, para ele, completamente desvinculado do passado.

Sabemos que Lázaro narra sua vida no momento em que se encontra no que considera ser a prosperidade: ele tem um oficio real, é um pregoeiro, além de ser favorecido pelo Arcipreste de Sant Salvador, quem Ihe arranjou o casamento com uma de suas criadas.

Para ele, sua vida é plena, a não ser pelo "caso" que tem de explicar a Vuestra Merced. Lázaro vive com os comentários sobre o adultério de sua esposa com o Arcipreste, mas prefere ignorá-los, recusando a existência do adultério e mantendo o estilo de vida que tinha então.

Acontece que, em alguns dos comentários de Lázaro, encontramos sérias críticas àqueles religiosos que mantinham relações amorosas, ou mesmo à hipocrisia vivida pelos membros da Igreja que não praticavam aquilo que pregavam. Tais críticas seguramente poderiam referir-se à situação vivida pelo narrador.

É contraditório que, vivendo sob a proteção de um membro da Igreja, a personagem pronuncie comentários críticos que possam atingi-lo. Lázaro não pretende abandonar a prosperidade que crê haver encontrado, e os comentários que faz parecem contradizer a sua atitude.

Em outros comentários, Lázaro critica a forma como a aparência é importante para a sociedade em que vivia. Usando principalmente o escudeiro como exemplo, critica a alienação daqueles que assumindo uma imagem, acreditam ser o que aparentam ser, não o que são realmente. 
Mas Lázaro, contraditoriamente, é um grande exemplo de tal alienação. Vestindo-se como homem de bem e ostentando tal imagem, acreditou sê-lo. Lázaro acredita ser o que aparenta ser, parece ser um homem honrado e se vê como tal, ignorando por completo a situação desonrosa em que vive.

A personagem é tão alienada quanto aqueles que criticados por ela, ela é capaz de olhar criticamente para a vida que tinha o escudeiro, mas é incapaz de perceber que tem a mesma atitude.

Talvez essa seja uma das maiores contradições do Lazarillo de Tormes. Lázaro consegue descrever o olhar crítico que tinha quando jovem, mas não consegue aplicar esse mesmo olhar crítico em sua vida atual.

As contradições presentes no discurso de Lázaro vão além de simples críticas aos representantes da Igreja ou à sociedade de aparências em que vivia. As contradições de Lázaro apontam para um individuo completamente alienado, incapaz de enxergar a si mesmo. Lázaro como narrador é capaz de relatar o seu passado preservando o olhar crítico que tinha, mas, paradoxalmente, já não possui esse olhar.

É somente no final do relato que o leitor se dá conta de tal contradição. Depois de expor de forma tão crítica a sua história de vida, depois de uma série de denúncias em seu discurso, Lázaro explica o "caso" que motivou a sua escrita.

Com o caso, o leitor percebe que a prosperidade que Lázaro diz ter atingido tem para ele um preço alto, a sua honra. Mas o leitor percebe também que, em meio a toda a ironia e ambigüidades presentes nesta parte do relato, Lázaro prefere ignorar os comentários sobre o adultério de sua esposa, aceitando a versão dela e do Arcipreste dos fatos, a assumir uma posição em defesa de sua honra. 
Sabemos a importância da honra para esta sociedade. Intimamente relacionada à imagem de alguém, a honra determinava o tipo de pessoa que se poderia ser. Lázaro, que já havia relatado toda a sua vida e o que aprendeu com suas experiências, conhecia o valor da honra.

Ele acreditava ser honrado naquele momento e, ignorando e negando os comentários que chegavam até ele, tinha a sua imagem preservada.

Depois de todo o relato da vida de Lázaro, o leitor espera um comentário crítico do narrador frente ao caso que protagoniza ao lado de sua esposa e do Arcipreste, mas isto não acontece. Existem ambigüidades e ironia na explicação do caso, mas nenhuma crítica é feita por Lázaro.

A ironia e as ambigüidades presentes no relato do caso denunciam o adultério da esposa de Lázaro, mesmo que o discurso do pregoeiro aponte para o contrário. Parece-nos que a ironia e a ambigüidade no último trecho do discurso de Lázaro foram utilizadas pelo autor implícito como uma forma de demonstrar ao leitor a real situação em que se encontrava a personagem.

Lázaro nega o adultério, mas o seu discurso dá indícios de que esse adultério talvez seja real. Ele diz viver em plena prosperidade, mas na explicação do caso fica clara a desonra em que vive. O leitor percebe que a exposição do caso envolve não simplesmente o adultério, mas a forma como Lázaro lida com ele e com a sua realidade.

A personagem foi corrompida pelo meio em que vivia. Este Lázaro já não olha criticamente para o mundo, estando integrado socialmente, o pregoeiro não critica a sociedade da qual é membro. Ele assimilou tudo o que antes era para ele motivo de crítica. 
Mais que críticas aos representantes da Igreja ou à sociedade de aparências, o Lazarillo de Tormes trata da incapacidade de um indivíduo de perceber a realidade em que vive.

Ele expressa comentários críticos relacionados ao seu passado, mas não percebe que tais críticas se aplicariam também ao seu presente. Ao criticar os representantes da Igreja por sua hipocrisia, Lázaro não vê que essas críticas se aplicariam ao Arcipreste, ao criticar a vida que tem o escudeiro, baseada somente em sua imagem, a personagem não percebe que se tornou uma caricatura de seu antigo amo.

Tal é o sentido do Lazarillo: a representação de um homem que perdeu a capacidade crítica que possuía conforme ia assimilando os valores da sociedade a que pertencia, uma sociedade baseada nas aparências onde parecer ser era o mesmo que ser algo. Lázaro impunha uma imagem e acreditou ser o que parecia ser, ele já não era capaz de ver quem era realmente, ele não via criticamente a vida que realmente vivia. 


\section{CONCLUSÃO}

O Lazarillo de Tormes é o retrato de uma época. O relato da vida de Lázaro e de sua "ascendência social" representa a forma como estava organizada a sociedade espanhola do século XVI e os seus principais valores.

Esse retrato, como observamos, é reforçado pelo forte tom realista adotado na obra. Abandonando os elementos fantásticos freqüentes em outras obras da época, o Lazarillo representou a vida de um marginal de forma verossímil e realista, tendo como ambiente um meio social completamente corrompido.

O autor desse romance, que preferiu se manter no anonimato, soube expressar dentro da obra o seu olhar crítico em relação a essa sociedade. Através do autor implícito, o seu alter ego dentro da obra literária, observamos como tal autor pôde representar o seu ponto de vista ora de forma explícita, como ocorre no prólogo, ora mascarado como ocorre ao longo da narrativa.

Vimos, neste trabalho, que reconhecendo a voz do autor implícito no Lazarillo, é possível desenvolver uma outra leitura da obra que não reconheça somente a voz do narrador, mas a relação entre essas vozes e a forma como se constrói o sentido da obra a partir delas.

Essas vozes se encontram ao longo do romance e, muitas vezes, esse encontro de diferentes perspectivas - do narrador e do autor implícito - forma contradições no discurso do narrador. 
Ao reconhecer as contradições do discurso do narrador, pudemos diferenciar as duas perspectivas que as formam e então analisar as relações estabelecidas entre elas.

O prólogo da obra, como dissemos, é o único espaço onde encontramos a voz do autor implícito expressa abertamente. Nele não há um conflito entre diferentes perspectivas, pois somente uma voz é expressa nessa parte da obra. $O$ estudo do prólogo possibilitou que reconhecêssemos algumas características desse autor, tais como a sua erudição e olhar crítico.

O autor implícito que encontramos no prólogo foi um prenúncio do que encontraríamos no discurso de Lázaro. O prólogo, além de apresentar os elementos que normalmente compunham um prólogo comum à época, apresenta, como comprovamos, as primeiras contradições do romance e um alerta ao leitor a respeito da postura que deveria adotar ao ler essa obra, já que ele deveria escolher um tipo de leitura a desenvolver - mais ou menos aprofundada.

Dando ao leitor opções para o tipo de leitura que desenvolveria, o autor implícito dividiu com ele a responsabilidade pelo sentido da obra, pois o tipo de leitura que desenvolvesse esse leitor poderia influenciar o sentido final do romance.

Pensando na construção do sentido do romance, começamos pelo narrador, Lázaro de Tormes, que relata a sua história no momento em que considera haver encontrado a prosperidade. Para ele, sua vida seria um exemplo de crescimento graças ao seu esforço pessoal e, contar a sua trajetória até a prosperidade, nada mais seria que uma exaltação de seu valor. 
Lázaro narra como sobreviveu às adversidades que surgiam em seu caminho com os diferentes amos a que serviu, conta o que aprendeu com eles e não deixa de apresentar algumas críticas ao estilo de vida que levavam.

Apesar do olhar crítico que apresenta na narrativa, pudemos perceber que tal olhar está restrito ao passado da personagem. Lázaro observa o seu passado e é capaz de recordar olhar crítico que possuía dando voz aos pensamentos que tinha quando criança ou adolescente. Como narrador, Lázaro também critica acontecimentos e personagens de seu passado, mas não critica o seu presente em momento algum.

Comprovamos que para Lázaro, criticar acontecimentos ou pessoas que fizeram parte de seu passado é mais uma maneira de exaltar o seu crescimento pessoal. Ele critica o que vivenciou, explicita o quanto foi difícil vencer as adversidades que encontrou pelo caminho e consegue com isto valorizar o que conquistou no presente.

Mas como vimos, o Lázaro que se encontra na "prosperidade" já não é o mesmo de antes. Esse Lázaro foi corrompido pelo meio em que vivia, ele assumiu os valores que antes criticava e perdeu o olhar crítico que possuía. A personagem já não é capaz, no presente, de olhar criticamente para o mundo ou para si mesma.

Essa é uma das grandes contradições da obra: o olhar crítico de Lázaro se perdeu conforme ele se integrava socialmente, mas ao relatar o seu passado, a personagem consegue recordar o olhar que tinha.

O pregoeiro não consegue se posicionar criticamente frente ao caso que protagoniza ao lado de sua esposa e do Arcipreste. Ele vive uma realidade de 
aparências, alienado e crente em sua boa fortuna, da mesma forma como vivia o seu antigo amo, o escudeiro.

Mais cego do que o seu primeiro amo, Lázaro não percebe a situação que vivencia. Preservando a sua imagem, o pregoeiro prefere ignorar os comentários de adultério de sua esposa e manter a vida "próspera" que considera ter.

O narrador nega o adultério de sua esposa, porém, seu discurso o trai. $\mathrm{O}$ relato do caso, cheio de ambigüidades e ironia, apesar de contar com a sua negativa, aponta para uma denuncia do adultério.

Com a exposição do caso se evidenciou a oposição dos pontos de vista de Lázaro e do autor implícito. Por um lado, compreendemos que Lázaro queria exaltar o seu crescimento social, e é claro, manter a sua prosperidade, além disso, vimos que ele já não era capaz de olhar criticamente para a vida que tinha, pois longe de representar a prosperidade, tal vida era um exemplo de desonra.

Por outro lado, reconhecemos o olhar crítico do autor implícito denunciando a corrupção de Lázaro. Tal denúncia é clara se pensarmos que a personagem que se mostrava crítica frente à sua realidade, vai perdendo a sua capacidade crítica conforme se integra socialmente.

Ao apresentar duas perspectivas diferentes, a sua e a do narrador, pudemos perceber que o autor implícito pretendia expor o processo de corrupção de Lázaro, e mais, ele representou, a partir do relato da vida de uma personagem marginal, a decadência de uma sociedade que vivia de forma hipócrita e corrupta onde o crescimento social, quase inexistente, seria possibilitado somente através da corrupção pessoal e da assimilação dos valores que regiam esse meio. 
Lázaro é um retrato da corrupção social daquele momento. A hipocrisia em que viviam muitos e a importância dada às aparências, valores que organizavam aquela sociedade, tornaram-se evidentes na narrativa do pregoeiro, fruto desse meio. $O$ narrador não nasce integrado socialmente e, sendo um marginal dentro dessa realidade, era capaz de observá-la e criticá-la sem comprometimento, porém ao integrar-se socialmente, aquilo que antes era motivo de crítica é também parte dele. Assumindo os valores que criticava, a personagem já não podia criticá-los porque eles a integravam.

As contradições do Lazarillo são a forma pela qual o autor implícito pôde expressar o seu ponto de vista sobre a realidade de uma época. Ele se fez ouvir em meio ao discurso de uma personagem completamente alienada, e é exatamente na conjunção de dois olhares tão diferentes que se construiu o sentido desse romance picaresco.

Foi somente ao reconhecer a voz do autor implícito no discurso de Lázaro que pudemos compreender como se constrói o sentido do Lazarillo. Esse romance representa mais que a vida de uma personagem e o seu processo de corrupção, ele representa a denuncia da corrupção do indivíduo que fazia parte de uma sociedade. Lázaro representa o processo de assimilação dos valores corrompidos da sociedade espanhola da época por aqueles que estavam inseridos nela. 


\section{REFERÊNCIAS BIBLIOGRÁFICAS}

AGUADO-ANDREUT, S. Algunas observaciones sobre el Lazarillo de Tormes. Guatemala, Ed. Universitaria, 1965.

ANÓNIMO. Lazarillo de Tormes. Madrid: Cátedra, 2002.

ASEGUINILAZA, F. C. El concepto de género y la picaresca. Santiago de Compostela: Universidade de Santiago de Compostela, 1992

AYALA, F. El Lazarillo: Nuevo examen de algunos aspectos. Madrid: Taurus ediciones, 1971. p.74

BAKHTIN, M. Estética da criação verbal. São Paulo: Martins Fontes, 2003.

BATAILLON, M. "Introduction". In: La vie de Lazarillo de Tormes. Paris, 1958. Tradução ao espanhol: Novedad y fecundidad del Lazarillo de Tormes. Madrid: Anaya, 1958.

BATAILLON, M. El sentido del "Lazarillo de Tormes". Librairie des éditions espagnoles, Paris-Toulouse, 1954.

BATAILLON, M. Le roman picaresque. Paris, 1931.

BLANCO AGUINAGA, C., RODRíGUEZ PUÉRTOLAS, J., ZAVALA, I. M. Historia social de la Literatura española (en lengua castellana) I. Madrid: Editorial Castália, 1981. 
BELIC, O. "Los principios de composición en la novela picaresca". In: Análisis estructural de textos hispanos. Madrid: Prensa Española, 1969, p.19-60.

BENJAMIN, W. "O narrador. Considerações sobre a obra de Nikolai Leskov". In: Magia e técnica, arte e política: ensaios sobre literatura e história da cultura. São Paulo: Brasiliense, 1994.

BOBES NAVES, M. del C. La novela. Madrid: Editorial Síntesis, 1993.

BOOTH, W. C. A retórica da ficção. Lisboa: Arcádia, 1980.

BRAIT, B. A personagem. São Paulo: Ática, 2000.

BRANCAFORTE, B. "La abyección en el Lazarillo de Tormes". In: Cuadernos Hispanoamericanos, 387, 1982, p. 551-556.

CANDIDO, A. et alii. A personagem de ficção. São Paulo: Editora Perspectiva, 1981.

CARRILLA, E. Maneirismo y Barroco en las literaturas hispánicas. Madrid: Editorial Gredos, 1983.

CASTRO, A. "Perspectiva de la novela picaresca" in Revista de la Biblioteca, Archivo y Museo del Ayuntamiento de Madrid, XII, 1935, p.123-138. Reimpr. In: Hacia Cervantes. Madrid, Taurus, 1957, p.83-105. 
CASTRO, A. El pensamiento de Cervantes (Ed. ampliada y con notas del autor y de Julio Rodríguez Puértolas). Barcelona, Noguer, 1972.

CASTRO, A. Prólogo a La vida de Lazarillo de Tormes (Ed. de E.W.Hesse e H.F.Williams), Madison, 1948. Reimpr.: "El Lazarillo de Tormes". In: Hacia Cervantes. Madrid, Taurus, 1957, p. 135-141.

CROS, E. Literatura, ideología y sociedad. Madrid: Editorial Gredos, 1986.

DAL FARRA, M. L. O narrador ensimesmado. São Paulo: Ática, 1978.

DEHENIN, E.: "Lazarillo de Tormes en la encrucijada de enunciación y enunciado". In: Actas del VI Congreso Internacional de Hispanistas. Toronto, 1980.

DEL MONTE, A. Itinerario de la novela picaresca española. Barcelona: Editorial Lúmen, 1971.

FRANCIS, A. Picaresca, Decadencia, Historia. Madrid: Editorial Gredos, 1978.

FRENK, M. "Lazarillo de Tormes: Autor-Narrador-Personaje". In: Romania Europea et Americana. Feschrift für Harri Meier. Bonn, 1980, p.185-192.

GARCÍA DE LA CONCHA, V.: Nueva lectura del Lazarillo. Madrid, Castalia, 1981.

GENETTE, G. Discurso da Narrativa. Lisboa: Vega, 1972

GÓMEZ MORIANA, A. "Sobre la función del 'yo' narrante en el Lazarillo de Tormes". In: Boletín de Filología Española, 42-45, 1972. 
GONZÁLEZ, M. M. A Saga do anti-herói: estudo sobre o romance picaresco espanhol e algumas de suas correspondências na literatura brasileira. São Paulo: Nova Alexandria, 1994.

GONZÁLEZ, M. M. "Lazarillo de Tormes: Estudo Crítico". In: Lazarillo de Tormes/ Edição de Medina del Campo, 1554. São Paulo: Editora 34, 2005.

GUILLÉN, C.: "La disposición temporal del Lazarillo de Tormes". In: Hispanic Review, XXV, 1957, p. 264-279.

GUILLÉN, C. "Genre and coutergenre: the Discovery of the picaresque". In: Literature as system: essays toward of literary history. Princenton: Princenton University Press, 1971.

HAUSER, A. Historia social de la literatura y el arte (Segundo tomo). Madrid: Ediciones Guadarrama, 1969.

HAUSER, A. Maneirismo. São Paulo: Perspectiva, 1993.

JAÉN, D.T. "La ambigüedad moral del Lazarillo de Tormes". In: Publications of the Modern Language Association of America, LXXXIII, 1968, p.130-134.

KAYSER, W. Análise e interpretação da obra literária. Coimbra: Armênio Amado Editor, 1958.

KAYSER, Wolfgang. "Qui raconte le roman?". In: Poétique 4. Paris, Seuil, 1970. p. 498-510. 
LÁZARO CARRETER, F. Lazarillo de Tormes en la picaresca. Barcelona, Ariel, 1983.

LEFEBVE, M. J. Estrutura do discurso da poesia e da narrativa. Coimbra: Livraria Almedina, 1976.

LEITE, L. C. M. O Foco Narrativo. São Paulo: Ática, 1989.

LIMA, L. C. Sociedade e Discurso ficcional. Rio de Janeiro: Editora Guanabara, 1986.

LIMA, L. C. A literatura e o leitor: textos de estética da recepção. São Paulo: Paz e Terra, 2002.

LUBBOCK, P. Técnica da ficção. São Paulo: Cultrix e Editora da Universidade de São Paulo, 1976.

MALDONADO DE GUEVARA, F. Interpretación del Lazarillo de Tormes. Madrid: Universidad de Madrid, 1957.

MENDILOW, A. A. O tempo e o romance. Porto Alegra: Editora Globo, 1972.

NAVARRO DURÁN, R."Introducción". In: VALDÉS, Alfonso de. La vida de Lazarillo de Tormes, $y$ de sus fortunas y adversidades. Barcelona: Ediciones Octaedro, 2003. 
PALMA, G. M. O Prólogo na obra de Gil Vicente. 1999. 206 f. Tese de doutorado apresentada à Faculdade de Filosofia, Letras e Ciências Humanas da Universidade de São Paulo, São Paulo, 1999.

POUILLON, J. O tempo no romance. São Paulo: Cultrix e Editora da Universidade de São Paulo, 1974.

PORQUERAS MAYO, A. El prólogo como género literario: su estudio en el siglo de oro español. Madrid: Ibarra, 1957.

OLIVEIRA, M. de L. A. de. "Alencar e Camilo: os prólogos como legitimadores do novo espaço literário", disponível em: http://www.realgabinete.com.br/coloquio/3 coloquio outubro/index.htm, acesso em 05 de junho de 2008.

RICO, F. "Introducción": In: La novela picaresca española, I. Barcelona: Planeta, 1967.

RICO, F. Problemas del Lazarillo. Madrid: Ediciones Cátedra, 1988.

RICO, F. La novela picaresca y el punto de vista. Barcelona: Editorial Seix Barral, 1989.

RODRÍGUEZ-PUÉRTOLAS, J. "Lazarillo de Tormes o la desmitificación del imperio". In: Literatura, historia, alienación. Barcelona, 1976, p.173-199.

SALAS, M. Claves de El Lazarillo Anónimo. Madrid: Ciclo, 1989. 
SOUILLER, D. La novela picaresca. México: Fondo de Cultura Económica, 1985.

TALÉNS, J. Novela picaresca y práctica de la transgresión. Madrid: Ediciones Jucar, 1975.

TODOROV, T. Os gêneros do discurso. São Paulo: Martins Fontes, 1980. 